\title{
Proposta para classificação, segundo a severidade, dos indivíduos portadores de más oclusões do Padrão Face Longa
}

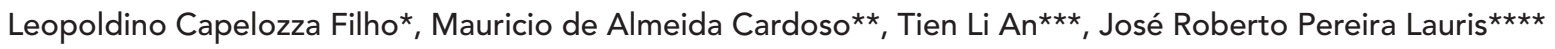

\section{Resumo}

Objetivo: o presente estudo teve como objetivo propor um método para classificação, segundo a severidade, dos indivíduos Padrão Face Longa, avaliando sua confiabilidade e reprodutibilidade. Metodologia: foram utilizadas fotografias faciais (frontal, perfil e frontal sorrindo) de 125 crianças Padrão Face Longa ( 54 do gênero feminino e 71 do gênero masculino), selecionadas apenas considerando-se a morfologia facial, com idades entre 10 anos e 6 meses e 15 anos e 2 meses. As fotografias foram avaliadas, separadamente, por três examinadores, sendo reavaliadas após três semanas, em uma nova disposição aleatória. Os indivíduos foram graduados em três subtipos, de acordo com a severidade: moderado, médio e severo. Para avaliar as concordâncias intra e interexaminadores, foi utilizada a estatística Kappa (k). Resultados: na avaliação intraexaminador, todos os examinadores obtiveram concordâncias substanciais, com o valor de Kappa variando de 0,64 a 0,66, havendo em todos os examinadores $80 \%$ ou mais de concordância. Quando comparadas as avaliações interexaminadores, as freqüências de concordância diminuíram, variando de 67,2\% a 70,4\%. A partir dos valores de Kappa, que variaram de 0,41 a 0,46, a interpretação foi considerada moderada. Conclusões: com base nesses resultados, o método foi considerado aplicável, com necessidade de complemento de informações provenientes de outros exames rotineiramente aplicados em Ortodontia. A aplicação clínica será demonstrada com intuito de evidenciar os níveis diferentes de severidade das más oclusões do Padrão Face Longa e as características do protocolo de tratamento recomendado.

Palavras-chave: Padrão face longa. Deformidades. Diagnóstico ortodôntico. Análise facial. Severidade.

\footnotetext{
* Professor Doutor da Faculdade de Odontologia da Universidade de São Paulo, USP-Bauru e membro do Setor de Ortodontia do HRAC da Universidade de São Paulo, USP-Bauru. Professor do Programa de Pós-graduação em Ortodontia da Faculdade de Odontologia de Araçatuba - UNESP.

** Mestre e Doutorando em Ortodontia pela Universidade Estadual Paulista, UNESP-Araçatuba. Professor de Graduação e Pós-Graduação da Universidade do Sagrado Coração, USC-Bauru.

*** Mestre e Doutorando em Ortodontia pela Universidade Estadual Paulista, UNESP-Araçatuba.

**** Professor Associado do Departamento de Odontopediatria, Ortodontia e Saúde Coletiva da Faculdade de Odontologia de Bauru da Universidade de São Paulo, USP-Bauru.
} 


\section{INTRODUÇÃO}

A denominação Face Longa representa um estigma na perspectiva convencional das classificações das más oclusões ${ }^{4,5}$. Sugere a presença de grandes desvios morfológicos em relação ao padrão normal ${ }^{10,11,14}$, com freqüente e significativo impacto estético. Desde há muito, na prática ortodôntica, admite-se com mais liberalidade que, para esses indivíduos, quando a face é desagradável, um procedimento ortodôntico-cirúrgico está indicado $4,5,10,11,31,50,51,53$.

Essa deformidade, na sombria perspectiva acima descrita, apresenta baixa incidência $(1,5 \%$ na população mundial ${ }^{20}$, manifesta-se precocemente, mantendo-se característica do indivíduo ${ }^{35}$, magnificandose ou não na adolescência ${ }^{18}$. Pode estar presente nas três relações dentárias sagitais, contudo, associa-se predominantemente às discrepâncias sagitais Classe $\mathrm{II}^{1,10,13,14,44,54 \text {. }}$

As crianças e adultos que manifestam esse excessivo crescimento vertical da face apresentam uma aparência característica, rotulada na literatura como "síndrome da face longa"5,8,40,41, tipo facial hiperdivergente ${ }^{20,31}$ e, recentemente, Padrão Face Longa ${ }^{10,13,14}$. Outras denominações, como "portadores de mordida aberta esquelética" ${ }^{2}$ ou "face de mordida aberta" ${ }^{135,36}$, desconsideram o erro esquelético primário $^{10,13,14}$ e são equivocadas, mesmo porque a mordida aberta, nesses indivíduos, ao invés de regra, é exceção ${ }^{13,15}$.

De um modo crítico, mas necessário, com base no contexto real das más oclusões do Padrão Face Longa, os trabalhos encontrados na literatura que utilizaram amostras selecionadas conforme critérios oclusais ${ }^{9,20,27,32,33,34}$ ou cefalométricos ${ }^{15,28,36,37,41,49}$ deveriam ser considerados com muita parcimônia. Esses critérios são absolutamente refutáveis na classificação desses indivíduos, o que compromete a veracidade das conclusões obtidas. Eles têm más oclusões que apenas refletem - não representam - a desarmonia esquelética e apresentam sinais importantes em seu tegumento, que envolvem áreas como a projeção zigomática, depressão infra-orbitária e sulco naso-geniano, que nem ao menos são visíveis ao exame radiográfico convencional.

Parece óbvia a necessidade de utilizar-se o padrão facial propriamente dito $^{8,13,14,18,22,38,39} \mathrm{ou}$, em outras palavras, denominar a doença e eleger os doentes, considerando-se a displasia esquelética como fator primário no estabelecimento da deformidade $1,2,4,20,40,42,47,51,53$.

A principal característica desses indivíduos é o excesso de exposição dentária ântero-superior, com os lábios em repouso, e dentogengival, durante o sorriso $^{1}$, ocasionado pelo aumento excessivo do terço inferior da face ${ }^{1,17,44,47,53}$. Na perspectiva clássica, esses sinais morfológicos seriam a essência da doença, gerando faces freqüentemente desagradáveis.

Desse modo, o tratamento ortodôntico isolado é muito limitado e um procedimento ortodôntico-cirúrgico configura, usualmente, a opção mais correta para a obtenção de uma estética, função e estabilidade adequadas ${ }^{10,11,13,14,18,50}$. Afinal, no protocolo de tratamento contemporâneo, a Ortodontia admite, de modo absoluto, que a cirurgia ortognática está indicada para o restabelecimento estético e funcional nos indivíduos com relações faciais comprometidas.

O diagnóstico do Padrão Face Longa baseia-se nas avaliações da morfologia facial e da cefalometria $^{1,4,5,10,11,14,17,53}$. A radiografia lateral da face constitui um instrumento necessário para ajudar a identificar a face longa, com o objetivo de localizar e quantificar a desarmonia esquelética, que pode estar associada a: um crescimento horizontal ou distal do côndilo $\mathrm{o}^{7,38} \mathrm{e} / \mathrm{ou}$ um crescimento posterior excessivo da maxila ${ }^{43,44}$. Esse exame, embora privado da imagem da projeção zigomática - reconhecidamente afetada na face longa ${ }^{10}$ - é de muita valia no diagnóstico diferencial, pois cada condição ostenta um diferente prognóstico para tratamento.

Revendo os objetivos desse exame, fica fácil entender que as expectativas em torno dele extrapolam aquilo que a cefalometria pode informar: uma tentativa frustrada de expressar forma por meio de números. Atingir os objetivos desse exame exige a avaliação morfológica da radiografia lateral da face, com atenção aos pontos cardeais que permitem 
identificar a presença da doença, sua localização e magnitude ${ }^{10}$.

A análise facial, primeiro exame na hierarquia diagnóstica, confere uma perspectiva mais adequada ao exame e qualificação da face longa, deformidade que, apesar do componente vertical primário, tem expressão tridimensional. Desse modo, além de conferir tons mais realistas às inúmeras características comuns a esses indivíduos - identificáveis nas radiografias, tais como: ausência de selamento labial passivo e contração do músculo mentoniano durante o fechamento labial ${ }^{1}$, grande exposição dos incisivos superiores, quando os lábios encontram-se em repouso, e gengival, durante o sorriso ${ }^{1,5,17,44,53}$ - agrega a visualização de outras características. O nariz é longo, observando-se estreitamento das bases alares, e o zigomático é, geralmente, plano, o que compromete a expressão facial. $O$ terço inferior da face alongado resulta em uma aparência retrognata da mandíbula ${ }^{1,17,19,23,38,44,47,53}$, gerando uma linha queixo-pescoço encurtada e um ângulo fechado entre a linha do queixo e o pescoço ${ }^{10}$.

A análise das relações dentárias desses indivíduos ajuda a entender porque as más oclusões do Padrão Face Longa, desde há muito, têm sido avaliadas por uma perspectiva diferente. $\mathrm{O}$ fator mais relevante é a impossibilidade de defini-las pela relação molar que, apesar da tendência para Classe II, pode ser Classe I e também Classe III (prevalências de 71,0\%, $13,2 \%$ e $15,8 \%$, respectivamente) ${ }^{13}$. Adicionalmente, a variação expressiva na morfologia da dentadura - que oscila de mordida aberta para sobremordida, trespasse horizontal negativo ou muito positivo, até presença ou não de mordida cruzada ${ }^{13}$ - desestimula o uso de referenciais dentários para sua denominação ${ }^{10}$. Além disso, considerando-se a limitação que esse padrão de crescimento impõe à abordagem ortodôntica, profissionais da cirurgia ortognática foram envolvidos no estudo e na caracterização dessas más oclusões. Eles, com base no diagnóstico morfológico permitido pela análise facial, contribuíram para uma definição mais adequada dos indivíduos Padrão Face Longa, livrando os portadores dessas más oclusões da equivocada classificação baseada primariamente na relação molar ${ }^{10,13}$.

Da mesma forma, parece ter sido estabelecida uma conotação estreita entre as más oclusões do Padrão Face Longa e sua severidade, com potencial para tornar a face desagradável e justificar a cirurgia. Isso não parece aplicável à prática clínica e não se justifica pelo conceito de Padrão Face Longa, conforme definido por Capelozza Filho ${ }^{10}$. No contexto desse conceito, no qual se enquadram todos os indivíduos impossibilitados de selamento labial passivo por desproporção entre os terços faciais, é licito admitir que a prevalência dessa má oclusão seja mais freqüente e com significativa variação de magnitude. Em outras palavras, além daqueles pacientes - reconhecidos como portadores da clássica face longa, com aumento do terço inferior da face, com desagradabilidade facial e indicação protocolar de cirurgia - muitos outros apresentam características desse padrão de modo variável, em presença e magnitude, requerendo protocolos individualizados.

Uma classificação por categorias distintas de severidade foi proposta por Tsang et al ${ }^{48}$ com o intuito de graduar as más oclusões de mordida aberta anterior, sem considerar o caráter esquelético e a repercussão facial. Entende-se que este tipo de classificação é limitada, considerando a variabilidade oclusal em indivíduos Padrão Face Longa, como já discutido anteriormente. Não há trabalhos na literatura que permitam graduar os indivíduos Padrão Face Longa de acordo com a severidade expressa pela face, muito embora a classificação das más oclusões, pela magnitude e etiologia, seja algo de grande importância para o clínico, uma vez que permite e amplia a capacidade prognóstica para suportar ou não a indicação de tratamento com Ortodontia/Ortopedia, seja ele interceptivo ou corretivo ${ }^{10}$.

Com essa perspectiva, o presente estudo tem como objetivo propor um método para classificação, segundo a severidade expressa pela face, os indivíduos portadores das más oclusões do Padrão Face Longa. A viabilidade do método proposto será questionada por meio da avaliação da sua confiabili- 
dade e reprodutibilidade, quando aplicada em uma amostra de indivíduos jovens, selecionada apenas considerando-se a morfologia facial. Admitindo-se sua validade, a aplicação clínica será demonstrada, com intuito de evidenciar os níveis diferentes de severidade das más oclusões do Padrão Face Longa e as características do protocolo de tratamento recomendado.

\section{MATERIAL E MÉTODOS Material}

O presente estudo foi aprovado pelo Comitê de Ética de Pesquisa em Humanos, da Universidade Estadual Paulista, Campus de Araçatuba (FOA 2005-01085). A amostra foi obtida com base na avaliação epidemiológica de 5.020 indivíduos matriculados no Ensino Fundamental ( $5^{\mathrm{a}}$ a $8^{\mathrm{a}}$ séries), em escolas das redes estadual, municipal e particular da cidade de Bauru, estado de São Paulo.

O tamanho da amostra foi calculado admitindose um intervalo de confiança de $95 \%$. A prevalência estimada do Padrão Face Longa na população, de acordo com a literatura, foi de $1,5 \%{ }^{20}$. Admitindose uma margem de erro de $0,35 \%$ na estimativa populacional, definiu-se um tamanho necessário de amostra de 4.643 sujeitos, utilizando-se a fórmula ${ }^{55} \mathrm{n}=\mathrm{z}^{2} \mathrm{pq} / \mathrm{d}^{2}$. Estimando-se possiveis perdas em torno de $10 \%$ da amostra, ficou determinado um tamanho de amostra final de aproximadamente 5.000 indivíduos, com a finalidade de se alcançar a precisão desejada.

Todos os indivíduos foram avaliados nas escolas e considerou-se unicamente a morfologia facial. O critério para seleção dos portadores de Padrão Face Longa foi a ausência de selamento labial passivo por desproporção dos terços faciais. As relações sagitais dos primeiros molares permanentes, bem como a relação vertical dos incisivos superiores e inferiores, não foram consideradas, de acordo com a proposta diagnóstica de Capelozza Filho ${ }^{10}$, em 2004.

Uma vez identificados, todos os indivíduos com fenótipo branco, portadores de Padrão Face Longa, foram contatados para uma avaliação em ambiente clínico. Ao todo, 125 indivíduos (54 do gênero feminino e 71 do gênero masculino) dispuseram-se a participar do presente estudo, no qual fotografias faciais (frontal, perfil e frontal sorrindo) foram realizadas, mediante prévia aprovação dos pais, por meio de termo de consentimento assinado. Determinou-se, como critério de inclusão, que o indivíduo não tivesse sido submetido a tratamento ortopédico e/ou ortodôntico prévio, nem apresentasse síndromes e/ou assimetrias clinicamente observadas. Todos os indivíduos selecionados apresentavam idades entre 10 anos e 6 meses e 15 anos e 2 meses, média de 12 anos e 9 meses (d.p.= 1 ano e 4 meses) para a amostra total, sendo 13 anos (d.p. $=1$ ano e 4 meses) e 12 anos e 6 meses (d.p. $=1$ ano e 3 meses) as médias e desvios-padrão para os gêneros feminino e masculino, respectivamente.

\section{Métodos}

As fotografias foram realizadas com os indivíduos em postura natural da cabeça, com os lábios relaxados, olhando para os próprios olhos refletidos em um espelho à sua frente, segundo o método proposto por Solow e Tallgren ${ }^{45,46}$, adaptado para a realização de fotografias faciais. Para tanto, foi utilizada uma câmera digital Nikon D-70 (Nikon Corp., Thailand, S.N. 3113472), com prioridade para FACE (manual), com lente Nikon $28-80 \mathrm{~mm}$ (Nikon Corp., Thailand, S.N. 3559428) travada na abertura, associada a um flash circular Macro Speedlight SB 29s (Nikon Corp., China, S.N. 2012836) em potência $1 / 4$.

A câmera fotográfica foi fixada a um tripé da marca Velbon DF 60 (Velbon, China, S.N. 1791540060), que teve sua altura ajustada para que o centro da lente estivesse compatível com o ponto subnasal, a uma distância de 90 centímetros do paciente.

Como plano de fundo para as fotografias, foi utilizada uma caixa de luz feita com uma estrutura de madeira (com medidas de $100 \mathrm{~cm}$ de altura, $68 \mathrm{~cm}$ de largura e $10 \mathrm{~cm}$ de profundidade, com 8 lâmpadas incandescentes de 100 watts em seu 
interior), coberta por um tecido branco, a $40 \mathrm{~cm}$ do paciente. Foi utilizada uma corrente metálica, fixada em um suporte que se localizava paralelo ao solo, distando $16 \mathrm{~cm}$ do paciente, equilibrada por um peso em sua extremidade, para que pudesse permanecer perpendicular ao solo.

Foi utilizado um espelho plano, de moldura oval, posicionado a $1,50 \mathrm{~m}$ do paciente, com o objetivo de auxiliar sua postura, de modo que pudesse olhar fixamente em direção aos seus olhos durante as tomadas fotográficas. Nas tomadas fotográficas frontal e frontal sorrindo, após o posicionamento do indivíduo com o espelho, este era removido previamente à tomada fotográfica. Todas as imagens fotográficas foram armazenadas inalteradas para posterior apreciação dos examinadores.

As imagens fotográficas frontal, de perfil e frontal sorrindo dos 125 indivíduos pertencentes à amostra foram avaliadas por três examinadores (A, B e C) com formação em Ortodontia e devidamente calibrados para avaliação da morfologia facial. Todas as imagens fotográficas foram numeradas para a apreciação dos examinadores, ocultando-se os dados como nome e idade dos indivíduos. A avaliação das imagens fotográficas foi realizada em ambiente escurecido, por meio de um notebook Toshiba Satellite A105-S4104 (Toshiba Corp., China, S.N. 66151049Q), com tela 15,4" widescreen.

Cada avaliação foi realizada separadamente e, após três semanas da primeira avaliação, as fotos dos indivíduos, em uma nova disposição aleatória, foram repassadas aos examinadores, para a realização de um segundo exame. Os resultados das avaliações foram anotados em uma ficha própria, entregue a cada examinador.

A confiabilidade de um método pode ser determinada mediante dois aspectos: sua capacidade de ser comparado (testes intra-examinadores) e sua reprodutibilidade (testes interexaminadores). Para avaliar a concordância intra e interexaminadores, foi utilizada a estatística Kappa (k) ${ }^{21}$.

O critério para a classificação dos indivíduos da amostra considerou a penetrância da displasia nos seus portadores, expressa nas relações faciais.
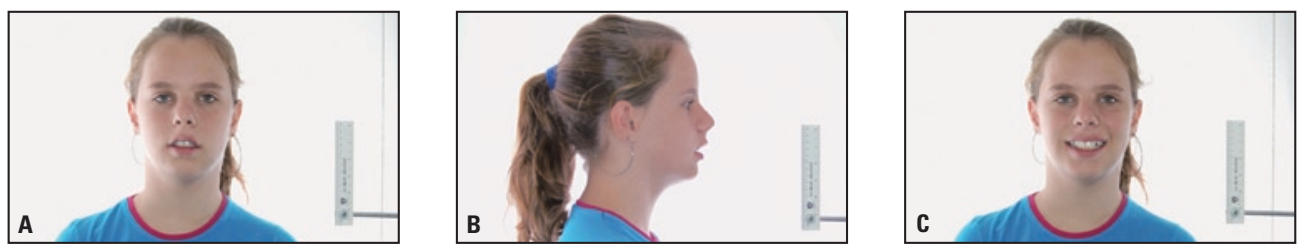

FIGURA 1 - Fotografias faciais de uma paciente Padrão Face Longa subtipo moderado.
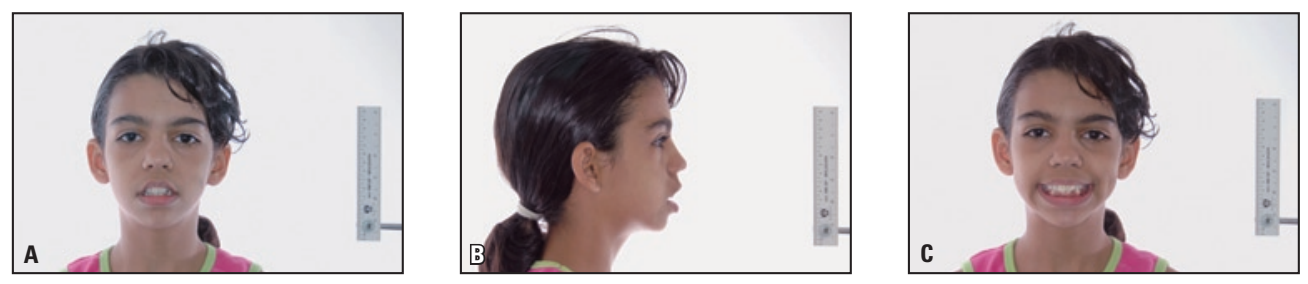

FIGURA 2 - Fotografias faciais de uma paciente Padrão Face Longa subtipo médio.
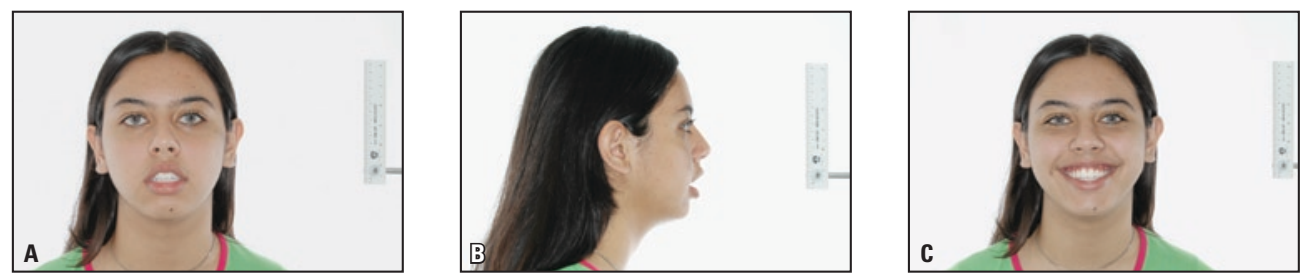

FIGURA 3 - Fotografias faciais de uma paciente Padrão Face Longa subtipo severo. 
Assim, os indivíduos foram classificados em três subtipos, de acordo com a severidade: moderado, médio e severo. De uma forma geral, os sinais típicos da displasia não precisavam necessariamente estar todos presentes e o exame frontal predominava, uma vez que a displasia é vertical.

Fixou-se como critérios de classificação para o subtipo moderado: presença obrigatória de incompetência labial, com exposição excessiva dos incisivos superiores no repouso e/ou de gengiva no sorriso; presença, mesmo que com componente postural, de moderada desproporção entre os terços médio e inferior. Em síntese, esses indivíduos poderiam ser considerados limítrofes para face longa, com prognóstico bom para tratamento conservador (ortodôntico e/ou ortopédico) (Fig. 1).

No que concerne ao subtipo médio, o critério de classificação foi a presença de uma desproporção verdadeira entre os terços médio e inferior, somada às características já descritas no subtipo anterior, determinando, portanto, sem dúvida, um indivíduo Padrão Face Longa. Nesses indivíduos, o prognóstico é regular para tratamento conservador (ortodôntico e/ou ortopédico) (Fig. 2).

Finalmente, os indivíduos pertencentes ao subtipo severo deveriam apresentar uma desproporção marcada entre os terços médio e inferior, somada às características descritas no subtipo anterior e acrescidas de mais sinais típicos da face longa, em magnitude suficiente para tornar a face desagradável. Nesses indivíduos, o prognóstico para tratamento conservador é ruim e a cirurgia ortognática está indicada para normalização das relações faciais (Fig. 3).

\section{RESULTADOS}

Os resultados da estatística Kappa, obtidos com base na verificação das concordâncias intra e interexaminador, estão apresentados, respectivamente, nas tabelas 1 e 2 . As freqüências dos subtipos dos 125 indivíduos Padrão Face Longa, classificados pelos três examinadores, estão apresentadas na tabela 3 .
Tabela 1 - Freqüência de concordância e valores de Kappa intra-examinadores.

\begin{tabular}{cccc}
\hline examinador & $\begin{array}{c}\text { frequiência de } \\
\text { concordância (\%) }\end{array}$ & Kappa & interpretação \\
\hline A e A & 81,6 & 0,66 & substancial \\
B e B & 80,8 & 0,65 & substancial \\
C e C & 80,0 & 0,64 & substancial \\
\hline
\end{tabular}

Fonte: Landis e Kock ${ }^{29}$.

Tabela 2 - Freqüência de concordância e valores de Kappa interexaminadores.

\begin{tabular}{cccc}
\hline examinador & $\begin{array}{c}\text { freqüência de } \\
\text { concordância (\%) }\end{array}$ & Kappa & interpretação \\
\hline A e B & 70,4 & 0,46 & moderado \\
B e C & 68,8 & 0,45 & moderado \\
A e C & 67,2 & 0,41 & moderado \\
\hline
\end{tabular}

Fonte: Landis e Kock ${ }^{29}$.

Tabela 3 - Freqüência dos subtipos do padrão face longa classificados pelos três examinadores num grupo de 125 indivíduos.

\begin{tabular}{|c|c|c|c|c|c|c|}
\hline \multirow{3}{*}{ categorias } & \multicolumn{6}{|c|}{ examinador } \\
\hline & \multicolumn{2}{|c|}{ A } & \multicolumn{2}{|c|}{ B } & \multicolumn{2}{|c|}{ C } \\
\hline & $\mathrm{n}$ & $\%$ & $\mathrm{n}$ & $\%$ & n & $\%$ \\
\hline subtipo 1 & 59 & 47,2 & 62 & 49,6 & 51 & 40,8 \\
\hline subtipo 2 & 61 & 48,8 & 59 & 47,2 & 66 & 52,8 \\
\hline subtipo 3 & 5 & 4,0 & 4 & 3,2 & 8 & 6,4 \\
\hline
\end{tabular}

Fonte: Landis e Kock ${ }^{29}$.

\section{DISCUSSÃO}

Muitos indivíduos portadores de Padrão Face Longa são submetidos a longos e, geralmente, inúteis tratamentos ortopédicos e/ou ortodônticos. A compreensão da origem desses insucessos está ligada não à ausência de diagnóstico, mas à falta de prognóstico. Admitindo-se que as limitações desses tratamentos, considerados conservadores, é reconhecida pela literatura ${ }^{10,50}$, parece claro que reveste-se de suma importância prognosticar a severidade da má oclusão e o impacto facial que o crescimento vai gerar. Nesse intento, não basta interpretar a deformidade facial e/ou a má oclusão presente em idade precoce, 
mas é necessário reconhecer a localização e, conseqüentemente, a etiologia primária da displasia.

Com essa perspectiva, um diagnóstico apropriado poderá ser feito, gerando um prognóstico e fornecendo suporte a metas terapêuticas realistas. Resumindo, a graduação da magnitude do impacto facial e a localização da displasia permitem ações terapêuticas mais consistentes ou, em outras palavras, correção das más oclusões associadas ao Padrão Face Longa, realizadas em consonância com a qualidade facial prevista ao final do crescimento. Isso significa tratamentos conservadores em faces que possam ser aceitáveis e cirúrgicos em faces que o crescimento e o tempo vão tornar desagradáveis.

Nesse propósito, a confiabilidade e a reprodutibilidade do presente método de avaliação, que objetiva a graduação de indivíduos portadores de Padrão Face Longa de acordo com a severidade, foi proposto e testado neste artigo. Nos resultados obtidos nas avaliações intra-examinadores, todos obtiveram concordâncias substanciais ${ }^{29}$ entre a primeira e a segunda avaliação (Tab. 1). Os valores de Kappa variaram de 0,64 a 0,66, com mais de $80 \%$ de concordância entre as avaliações realizadas com intervalo de três semanas. Com base nesses resultados, pode-se dizer que, com calibragem e treino, o método proposto permite confiabilidade diagnóstica substancial aos examinadores. Resumindo, o examinador, ao repetir o exame três semanas após, mantém, com alta probabilidade, a opinião diagnóstica emitida no primeiro exame.

Quando a reprodutibilidade do método foi avaliada por meio dos testes interexaminadores, as freqüências de concordância diminuíram, apresentando uma variação de $67,2 \%$ a 70,4\%, com os valores de Kappa oscilando entre 0,41 e 0,46 (Tab. 2). Dessa forma, a reprodutibilidade do presente método foi considerada moderada.

A variação ocorrida nas avaliações intra e interexaminadores, respectivamente, de substancial para moderado, representa uma limitação do método, mas não uma reprovação inexorável. Deve-se considerar que, na aplicação clínica dessa avaliação, não se propõe, nem como hipótese, que a análise facial seja única. Sabe-se da sua importância na hierarquia diagnóstica ${ }^{10}$ e reconhece-se, em absoluto, a colaboração que os outros exames de rotina, como a anamnese, a investigação radiográfica e de modelos dos arcos dentários, podem acrescer.

Por motivos inerentes à metodologia adotada nesta pesquisa, foi proposto aos examinadores que elaborassem, obrigatoriamente, um diagnóstico apoiado apenas no contexto facial. Além disso, tal procedimento foi feito não para rotular indivíduos de diferentes padrões, mas para graduar a magnitude da discrepância em indivíduos do mesmo padrão. Parece claro que seria exigir demais encontrar um nível de concordância maior do que moderado entre os diferentes examinadores. A confirmação dessa hipótese é sustentada pela variação intra-examinador (Tab. 1), na qual a concordância do diagnóstico emitido mais de uma vez pelo mesmo examinador alcançou índices melhores.

Com relação à classificação realizada pelos três examinadores, a freqüência dos subtipos, observada na presente amostra, apresentou variação (Tab. 3). Embora essa variação não possa ser considerada desprezível, a maioria dos indivíduos seria interpretada para tratamento de maneira mais adequada do que se simplesmente fossem vistos como portadores de Padrão Face Longa, sem considerar a magnitude. A comprovação para isso é clara, quando se constata nos resultados que sempre que um indivíduo foi avaliado diferentemente, seja intra ou interexaminadores, nunca foi levado para um nível que não fosse o mais próximo. Ou seja, as variações sempre foram de moderado para médio (ou vice-versa) ou de médio para severo ou vice-versa), sem nunca variar entre os extremos.

Em outras palavras, apesar da evidência apenas moderada de suporte estatístico, parece importante caracterizar a evidência de validade dessa classificação na perspectiva da prática clínica. Para cumprir esse desiderato, uma revisão do que caracterizaria cada um dos subtipos e os protocolos de tratamento adotados passa a ser descrita. 


\section{Padrão Face Longa subtipo moderado}

Os indivíduos pertencentes ao subtipo moderado (Fig. 1) são aqueles nos quais é possível especular que os fatores não-genéticos, de ordem local ou geral, são primários.

Identificados em idade precoce, a face longa moderada poderia ser ainda apenas postural, representando, morfologicamente, uma inadequação obrigatória entre os componentes funcionais internos e externos ${ }^{50}$. É reconhecido que há muito mais respiradores bucais de boca aberta do que indivíduos realmente portadores de face longa. De acordo com a literatura, a prevalência de aumento consistente ou anormal na altura da face anterior inferior é de 18\%, em uma amostra de indivíduos brancos do gênero masculino ${ }^{30}$, enquanto a prevalência esperada para indivíduos Padrão Face Longa é de apenas 1,5\% ${ }^{20}$.

Hábitos adquiridos ou obrigatórios, tonsilas faringeanas e palatinas hipertróficas, rinite alérgica, apnéia obstrutiva do sono, entre outros ${ }^{30}$, agindo em um tipo facial predisposto ${ }^{10}$, criariam faces com discrepância vertical ou Padrão Face Longa subtipo moderado. Seriam, conforme Linder-Aronson e Woodside $^{30}$, cópias ambientais de modelos genéticos.

Além deles, a implantação oblíqua do nariz em portadores de protrusão maxilar, poderia criar um modelo de face longa diferente. Com encurtamento do terço médio da face e impossibilitados de selamento labial passivo, esses indivíduos, submetidos aos desvios de postura e função, obrigatórios nessa situação, poderiam ser catalogados como Padrão Face Longa por encurtamento relativo do terço médio da face.

Para os portadores de más oclusões Padrão Face Longa moderada, esforços terapêuticos adequados teriam recompensas significativas. Independentemente do manejo no tratamento adotado por diferentes escolas ortodônticas ${ }^{3,6,10,24,54}$, um pouco mais de liberdade poderia ser adotada nos procedimentos, rompendo certas regras, como deixar de diminuir a massa dentária, obrigatória para os subtipos de face longa de maior severidade. Além dessa perspectiva estritamente ortodôntica, investimentos em pesqui- sa diagnóstica e tratamento interdisciplinar são absolutamente recomendados na busca por normalizar a parte funcional, como respiração e postura da musculatura intra e peribucal. Como se sabe, a mudança no modo de respirar e toda a competência postural e funcional que isso pode permitir parecem ser capazes de influenciar positivamente o crescimento ${ }^{30}$, especialmente em pacientes que guardam as características descritas para o subtipo moderado.

A paciente apresentada na figura 4 representa uma ocorrência clínica que poderia ser classificada como face longa moderada. Este caso tem o objetivo de abrir uma discussão sobre diagnóstico e prognóstico, principal interesse deste artigo.

A primeira consulta da paciente, aos dez anos de idade, foi motivada pelos "dentes para fora". A anamnese evidenciou o hábito de sucção de chupeta, para dormir, até os quatro anos de idade; boa saúde, respiração mista e predomínio da respiração bucal noturna. A análise facial mostrou, especialmente no aspecto frontal (Fig. 4A), uma desproporção moderada entre os terços faciais, com impossibilidade obrigatória de selamento labial passivo, postura hipotônica de ambos os lábios e participação compensatória da musculatura do mento na deglutição. A expressão facial estava presente, garantida por uma boa projeção zigomática, que formava a depressão infra-orbitária e o sulco naso-geniano. Esses sinais morfológicos caracterizavam um Padrão Face Longa do subtipo moderado.

O exame do perfil (Fig. 4B) comprovou essas evidências, mas deixando claro que não havia excesso no terço inferior da face, já que a face total não era longa. Uma linha queixo-pescoço, considerando a idade, razoável em termos de tamanho, guardando um ângulo aberto entre seus componentes, e moderadamente fechado com o plano de Camper, também era observada. Ao mesmo tempo, era possível observar uma implantação oblíqua do nariz, que diminuía a altura facial média e elevava o lábio superior. Admitindo-se a hipótese de uma face longa, ela ainda seria classificada como moderada, mas, fato novo, causada por um encurtamento do terço médio 

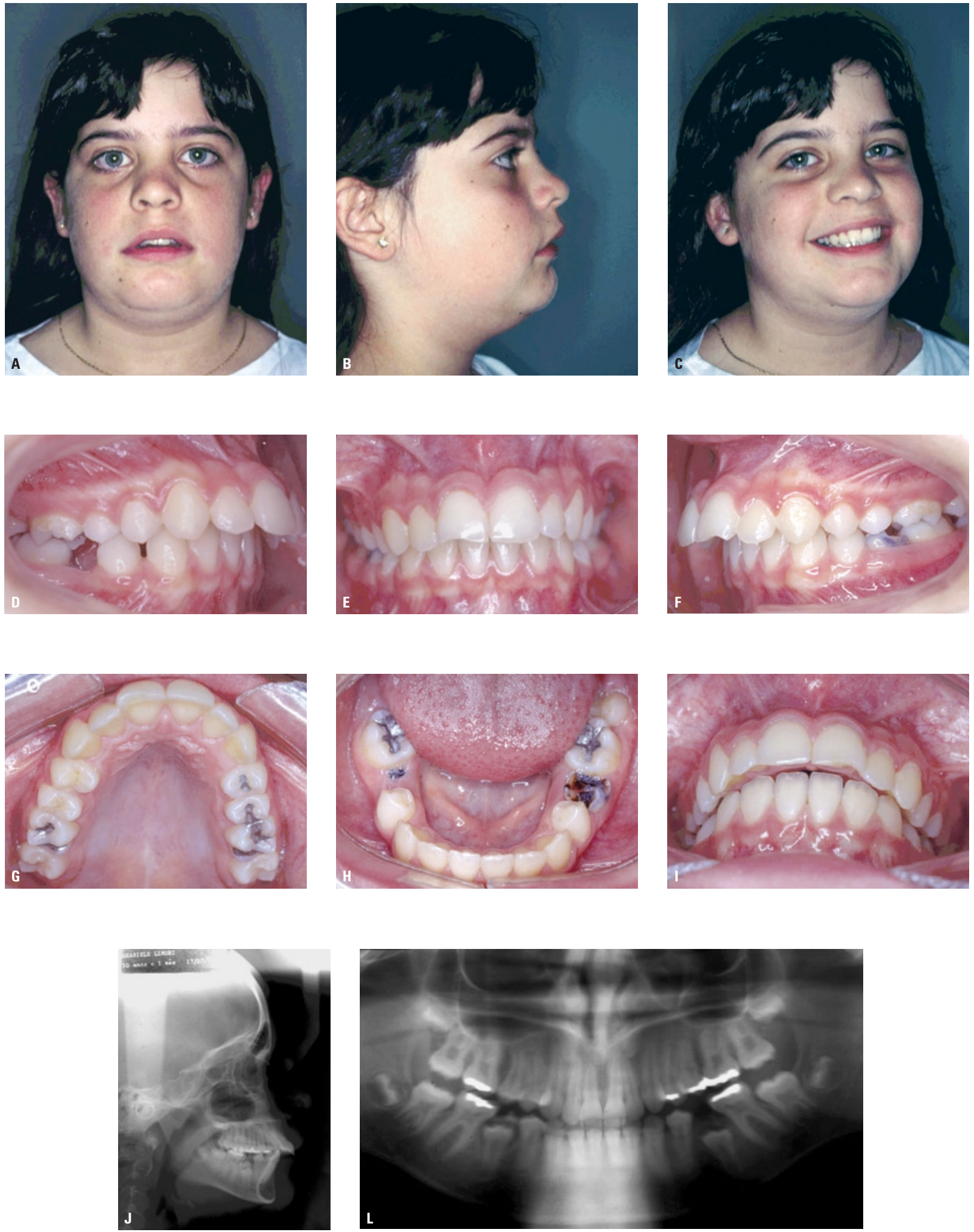

FIGURA 4 - Face (A-C), oclusão (D-I) e radiografias iniciais (J, L) de uma paciente, aos dez anos de idade, representando uma ocorrência clínica que poderia ser classificada como face longa moderada. 
da face ${ }^{10}$. Essas características obtidas na análise facial foram complementadas por outras informações geradas pela documentação ortodôntica solicitada.

Ainda na consulta, o exame clínico intrabucal (Fig. 4D-I) evidenciou uma dentadura mista no final do segundo período transitório, com presença apenas do dente decíduo 85 em estado terminal de rizólise, faltando irromper os segundos pré-molares inferiores (Fig. 4J). A relação molar era de Classe II total mais $1 / 4$ do lado direito e Classe II total do lado esquerdo, com trespasses horizontal e vertical de $9 \mathrm{~mm}$ e $5 \mathrm{~mm}$, respectivamente, e ausência de apinhamento. A manipulação da mandíbula mostrou moderada diferença entre MIH e RC, com desvio da mandíbula para frente e para esquerda. A deglutição era atípica, com evidente participação compensatória da musculatura do lábio inferior e mento. O diagnóstico efetuado ao final da consulta, respeitados os conceitos que norteavam a conduta clínica na época (1992), foi de uma má oclusão Classe II, $1^{\text {a }}$ divisão, com moderada protrusão maxilar.

O exame da documentação (Fig. 4J, L) não acrescentou nenhum dado relevante para a análise facial. O exame morfológico da radiografia lateral da face, já nessa época, substituía a cefalometria no contexto do diagnóstico e acrescentou fatos novos a ele. Pela perspectiva desse exame morfológico, a paciente tinha o limite vertical inferior da face compatível com o normal. Observe-se que a mandíbula tinha forma, tamanho e posição adequados (Fig. 4L). Se não for possível visualizar tais características, também não será possível mensurar e obter medidas confiáveis, com base no conceito contemporâneo, que não permite creditar à cefalometria correlação com morfologia facial.

A grande discrepância na radiografia era dentária, com um trespasse horizontal muito significativo, conforme detectado clinicamente. Como a posição dos incisivos inferiores era boa, dentro dos limites anatômicos da sínfise mandibular, a inclinação vestibular dos incisivos superiores era, provavelmente, o agente causal mais importante. Todavia, não parecia lícito admitir que todo erro sagital estivesse concen- trado apenas na inclinação vestibular dos incisivos superiores. Se a correção de todo o trespasse horizontal fosse executada apenas com a retração desses dentes, eles ficariam absolutamente mal posicionados na base óssea. Em outras palavras, o exame morfológico da radiografia lateral da face não suportava a idéia de que a correção ideal desse trespasse horizontal pudesse ser feita apenas com retração dos incisivos superiores. Portanto, parte desse erro era causada por protrusão maxilar, conforme evidenciado pela linha de implantação do nariz, no exame do perfil facial (Fig. 4B).

Embora não houvesse uma clara inclinação ascendente do plano palatino, que caracterizaria de modo inequívoco a protrusão maxilar, ela não pôde ser descartada - pela evidência de sua presença na face da paciente e pelo que se descreve a seguir. Parecia óbvio admitir que o hábito de sucção, relatado pelos responsáveis da paciente, deveria ser considerado como um fator etiológico consistente, assim como suas conseqüências no desequilíbrio da musculatura peribucal. Isso explicaria a inclinação vestibular dos incisivos superiores e a conseqüente protrusão, mas não justificaria o encurtamento do terço médio da face, que é um sinal morfologicamente claro e que, inexoravelmente, deve ser considerado no diagnóstico.

À luz de todas essas características evidenciadas pelos exames, pareceu razoável admitir que essa paciente pudesse ser classificada como foi, ao tempo do exame (1992), como portadora de uma má oclusão Classe II, protrusão maxilar. No conceito do diagnóstico morfológico com base no padrão facial que hoje se adota, isso seria traduzido para uma má oclusão do padrão II, protrusão maxilar e dentária superior, Classe II. Isso pode ser considerado correto, mas, certamente, não seria incorreto classificá-la, no contexto ora proposto, como portadora de uma má oclusão moderada do Padrão Face Longa, com encurtamento do terço médio da face.

A protrusão de maxila, caracterizada pela implantação oblíqua do nariz, encurtava o terço médio da face e criava uma discrepância vertical proporcional 
entre os terços médio e inferior, impedindo o selamento labial e criando, em conseqüência, características que permitiam também enquadrar a paciente como portadora de uma face longa moderada. Era impossível determinar nesse momento, aos 10 anos de idade e em um primeiro exame, se o encurtamento da face média, que gerava a discrepância entre a proporção dos terços faciais, era produzido exclusivamente por protrusão da maxila. Deve-se considerar que o encurtamento verdadeiro do terço médio da face também ocorre, embora sempre associado a uma implantação oblíqua do nariz, criando uma face longa de maior severidade e pior prognóstico ${ }^{10}$.

Essa paciente está situada em uma zona limítrofe para diagnóstico, que permite essa dubiedade. Os limites exatos da localização dessa paciente no espectro das más oclusões só foram demarcados pelos resultados que o padrão de crescimento permitiu à ação terapêutica. O importante, e isso foi demonstrado pelo tratamento adotado, é que a condução do caso seria similar dentro de qualquer um dos diagnósticos, já que a meta terapêutica foi praticamente a mesma. A redução da protrusão maxilar caracterizou-se como meta principal nesse tratamento e, junto com ela, a redução do erro dentário ou a correção da má oclusão de Classe II. O prognóstico, admitese, poderia ter sido diferente, já que há evidências de que a protrusão maxilar pode ser corrigida ${ }^{16,52}$, enquanto o encurtamento verdadeiro do terço médio da face não ${ }^{10}$.

$\mathrm{Na}$ perspectiva do diagnóstico elaborado, a paciente foi tratada com ancoragem extrabucal de tração média-alta, força ortopédica 14 horas por dia, com muita colaboração. O objetivo primário era corrigir a protrusão maxilar e contar com o efeito inexorável sobre a dentadura superior, que nesse caso também estava protruída e seria beneficiada. O tratamento, caso o diagnóstico tivesse sido de face longa moderada, provavelmente não seria diferente. Repetindo o descrito acima, o prognóstico seria diferente, mais pessimista, admitindo-se que o Padrão Face Longa não poderia ser alterado e manteria sinais na face da paciente.
No arco inferior, foi adaptada uma placa lábioativa, com o objetivo primário de incentivar o ajuste das relações labiais e secundário de manter o comprimento do arco inferior, enquanto os segundos pré-molares inferiores eram aguardados.

O tratamento foi iniciado aos 10 anos e 3 meses e, logo após a correção da relação molar, os aparelhos fixos foram instalados. Elásticos de Classe II foram utilizados após o nivelamento, para finalizar a correção das relações dentárias sagitais. O tempo total do tratamento foi de 1 ano e 10 meses.

As radiografias panorâmica e lateral da face, obtidas ao final do tratamento (Fig. 5), ainda com aparelho fixo, confirmaram as adequadas relações dentárias e faciais, incluindo maxila e mandíbula,
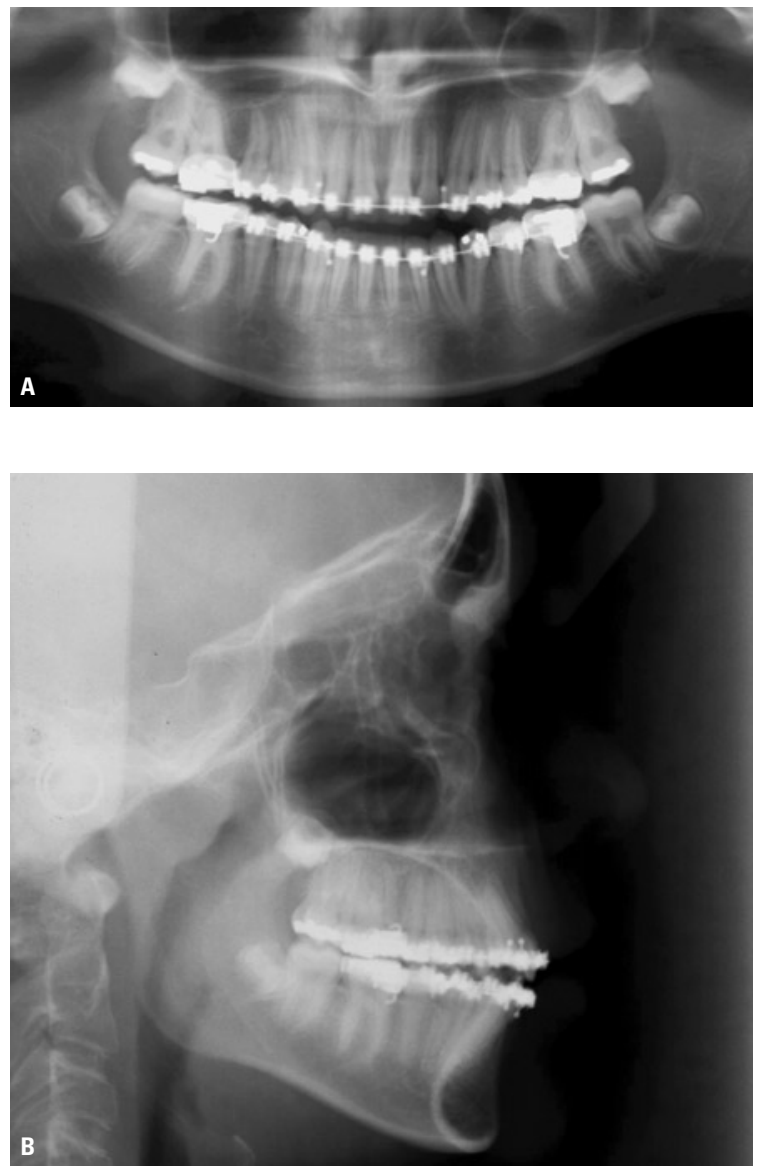

FIGURA 5 - As radiografias panorâmica (A) e lateral da face (B), obtidas ao final de 1 ano e 10 meses de tratamento, ainda com aparelho fixo, confirmaram as adequadas relações dentárias e faciais. A redução da protrusão maxilar caracterizou-se como a meta principal nesse tratamento e, junto com ela, a redução do erro dentário ou a correção da má oclusão de Classe II. 
tanto no sentido sagital quanto vertical. Parece, portanto, que o padrão de crescimento permitiu efeitos plenos à terapêutica primária adotada (compressão da maxila póstero-superior, por meio de força ortopédica aplicada na dentadura superior com ancoragem extrabucal).

Os resultados do tratamento foram bastante razoáveis para a oclusão, conforme evidenciado pelas fotografias obtidas um mês após a remoção dos aparelhos (Fig. 6A-E). A correção da dentadura foi absoluta no lado direito e, apesar do erro ainda presente na relação sagital do lado esquerdo, o reflexo do tratamento foi muito positivo nas relações dos incisivos. A paciente, então com 12 anos e 2 meses, apresentava relações faciais mais adequadas (Fig. 6F-H). Embora ainda possa se admitir alguma desproporção entre os terços faciais e alguma compensação na musculatura do mento, as melhoras foram evidentes.

O primeiro controle após o final do crescimento
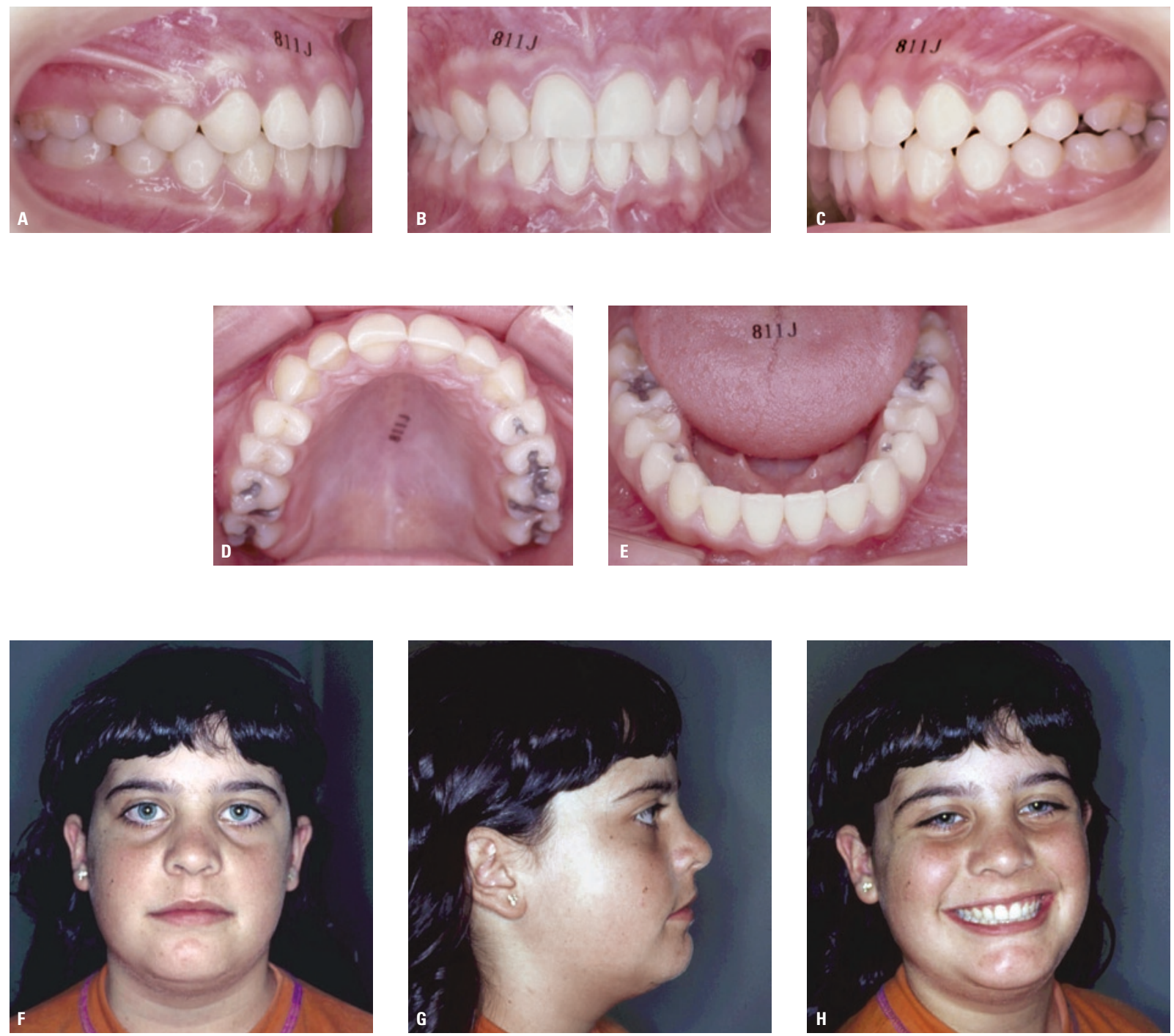

FIGURA 6 - Os resultados do tratamento foram bastante razoáveis para a oclusão, conforme evidenciado pelas fotografias obtidas um mês após a remoção dos apareIhos (A-E). A paciente, então com 12 anos e 2 meses, apresentava relações faciais mais adequadas (F-H). 
ativo, aos 15 anos de idade (Fig. 7A-H), evidenciou que a paciente não mostrava mais vestígios faciais daquilo que, no passado, poderia ter sido considerado uma face longa moderada. Ela poderia ser classificada como uma paciente padrão I. Então e só então - foi possível concluir que a paciente apresentava Padrão Face Longa moderado por encurtamento do terço médio, causado por protrusão maxilar. A correção não só foi possível, como suportada pelo período de crescimento livre de terapia que se seguiu ( 3 anos). A dentadura apresentava muita estabilidade, preservando as características presentes na finalização.

Bom que tenha sido assim, mas e se a paciente fosse realmente face longa? $\mathrm{O}$ crescimento teria limitado a terapia e o impacto do tratamento sobre as relações faciais; mas, ainda assim, poderia ser considerado bem sucedido, sendo suportado por um prognóstico menos otimista. Nessa perspectiva, não é difícil admitir que o diagnóstico de face longa moderada por encurtamento do terço médio causado por protrusão maxilar teria sido mais realista.
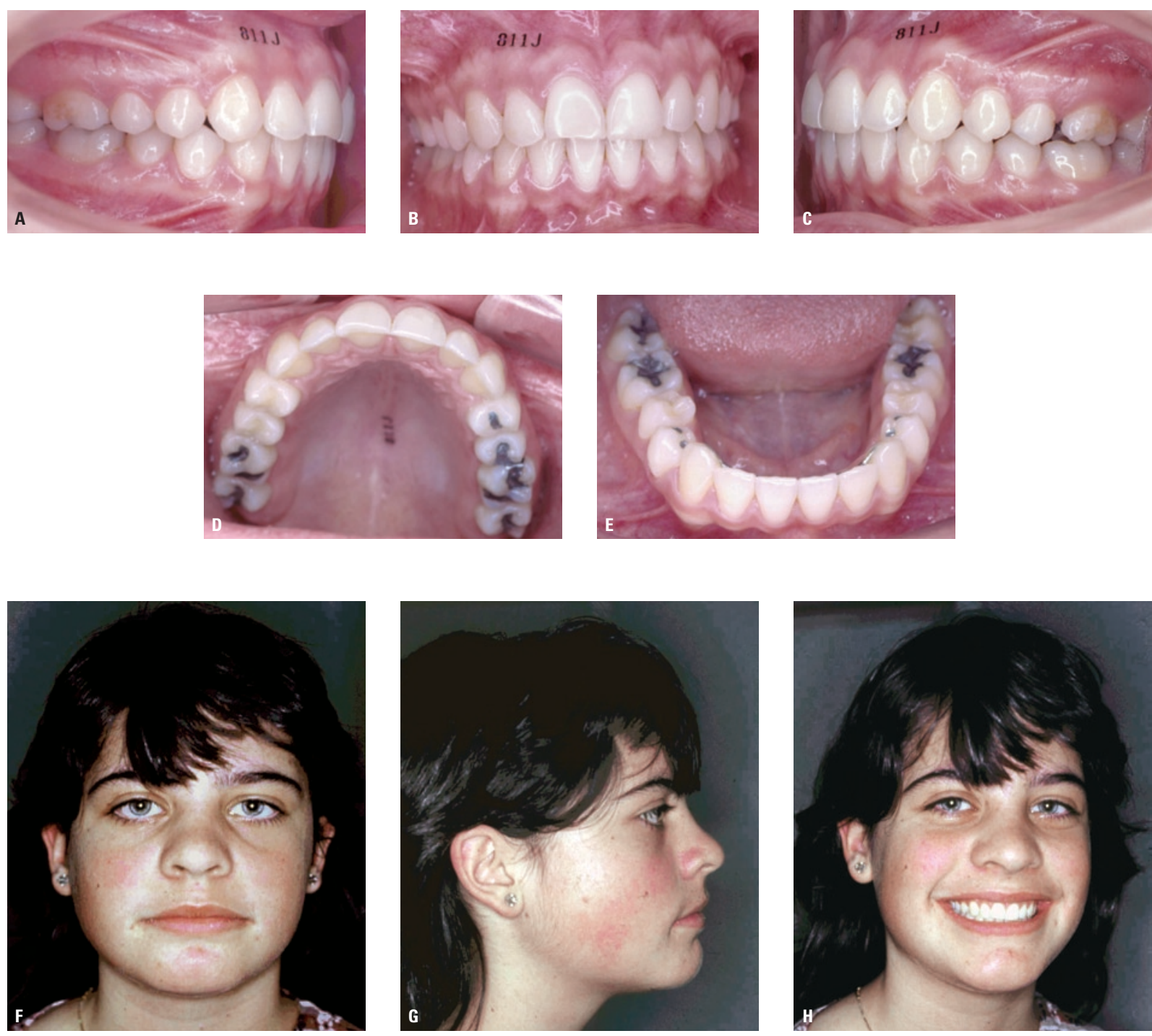

FIGURA 7 - Face e oclusão aos 15 anos de idade, 3 anos após a remoção dos aparelhos, evidenciaram que a paciente não mostrava mais vestígios faciais daquilo que, no exame inicial, poderia ter sido considerado uma face longa moderada. A dentadura apresentava muita estabilidade, preservando as características presentes na finalização. 


\section{Padrão Face Longa subtipo médio}

Em oposição ao aceito para o subtipo moderado, os indivíduos pertencentes ao subtipo médio não podem ser considerados produtos do meio ambiente. O profissional deve ter consciência da determinante genética no padrão facial observado. Mais do que a expressão facial e a má oclusão presente, é imperioso admitir a irreversibilidade do destino da morfologia facial. A caracterização da face nos indivíduos considerados como portadores de más oclusões do Padrão Face Longa, classificados como de severidade média, é mais intensa, facilitando sua identificação.

Nesse contexto, embora um tratamento conservador possa ser indicado, ele deve seguir as regras consideradas essenciais para o manejo desses indivíduos, sempre com intenção de não aumentar ou diminuir o volume intrabucal e exercitar a funcionalidade da musculatura intra e peribucal ${ }^{10,38} \mathrm{ou}$, em outras palavras, facilitar o equilibrio entre os componentes funcionais internos e externos ${ }^{50}$. Além disso, o prognóstico é duvidoso, obrigatoriamente pontuado por observações periódicas que avaliem a efetividade terapêutica e, assim, consolidem ou não o tratamento. Isso vale não apenas para a atuação ortodôntica, mas para todos os profissionais que estejam envolvidos no esforço interdisciplinar de tratamento.

Neste caso, a paciente apresentava 9 anos e 9 meses, no momento da consulta, e o motivo da avaliação foi a transferência de cidade. Encontrava-se em tratamento interceptativo, com placa expansora no arco superior e placa lábio-ativa no arco inferior, com objetivo de obtenção de espaço para alinhamento dos incisivos superiores e inferiores. $\mathrm{Na}$ anamnese, os responsáveis relataram respiração bucal, com piora durante o sono, predominantemente com boca aberta.

A análise facial (Fig. 8A-C) mostra que a penetrância da doença Padrão Face Longa era visivelmente maior. A incompetência labial obrigatória, característica desses indivíduos, estava marcada na face da paciente, com forte exposição dos incisivos superiores. $\mathrm{Na}$ análise do perfil facial, havia ausência de projeção zigomática, somada à desproporção entre os terços médio e inferior, caracterizando a face longa do subtipo médio. A expressão facial estava comprometida, assim como a agradabilidade facial.

$\mathrm{Na}$ avaliação da oclusão, a paciente encontravase no estágio do segundo período transitório da dentadura mista, com evidente discrepância de tamanho dentário em relação às bases ósseas, com prognóstico ruim para a relação dente $\mathrm{x}$ osso. Uma relação sagital de Classe I em caninos decíduos pôde ser observada, com desvio de linha média inferior para a direita, com falta de espaço para o dente 43 (Fig. 8D-H).

Uma documentação de rotina foi solicitada e a paciente encaminhada para um otorrinolaringologista, para avaliação do padrão funcional. Nesses pacientes, é imperioso orientar os responsáveis acerca da irreversibilidade do destino da morfologia facial. Em outras palavras, a meta buscada será a correção da oclusão, com sérias limitações à estética facial, que serão impostas pelo padrão de crescimento que, apesar de identificado e estimado, não pode ser adequadamente definido em termos de severidade.

A avaliação da documentação recebida não acrescentou nenhum dado importante à análise facial. O exame dos modelos dos arcos dentários e da radiografia panorâmica (Fig. 8I) confirmou a significativa discrepância de tamanho dentário em relação às bases ósseas.

A análise morfológica da radiografia lateral da face (Fig. 8J) confirmou a divergência dos planos palatino e mandibular, com aumento da altura do terço inferior da face. Parecia razoável admitir alguma discrepância entre a altura do ramo e o comprimento do corpo mandibular, o que seria característica de um crescimento distal de côndilo, com abertura do eixo facial e contribuição para face longa. Essa hipótese foi reforçada pela ausência de excesso posterior de maxila, já que a posição dos ápices das raízes dos molares superiores guardava uma boa relação com o plano palatino. Isso impli- 

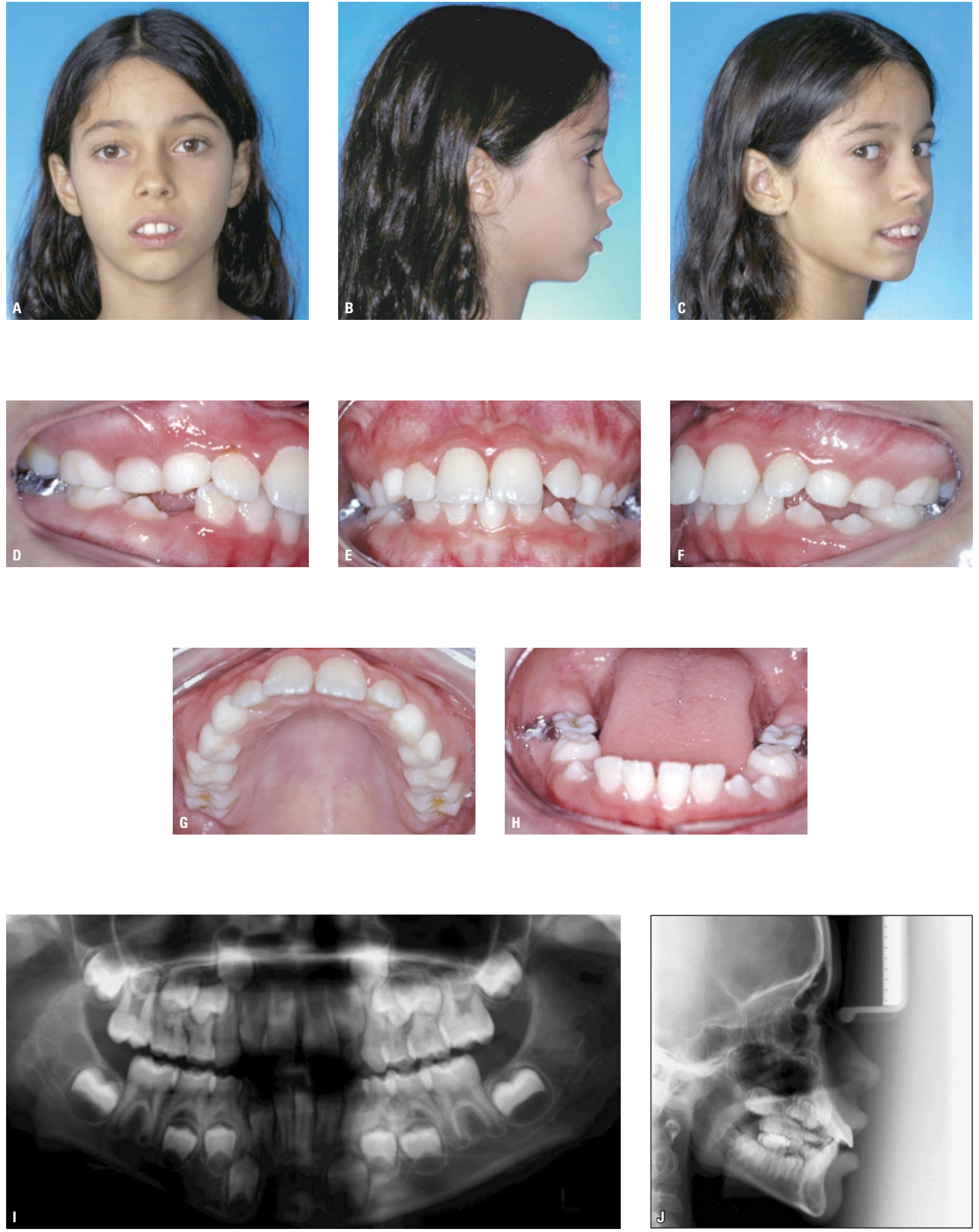

FIGURA 8 - Face (A-C), oclusão (D-H) e radiografias iniciais (I-J) de uma paciente face longa subtipo médio, aos 9 anos e 9 meses. 0 exame da radiografia panorâmica (I) confirmou a significativa discrepância de tamanho dentário em relação às bases ósseas, com falta de espaço presumida para a erupção dos dentes permanentes. A análise morfológica da radiografia lateral da face (J) confirmou um aumento da altura do terço inferior da face, com provável crescimento distal de côndilo. 
cou em admitir, necessariamente, que havia uma determinante genética para o crescimento vertical, muito difícil de ser quantificada em severidade potencial para a morfologia da face no futuro, considerando-se a tenra idade da paciente.

Desse modo, o diagnóstico foi de Padrão Face Longa subtipo médio, com provável crescimento distal de côndilo, dentadura mista, segundo período transitório. A paciente apresentava relação molar de Classe I, com perda de comprimento no arco inferior, desvio de linha média inferior para direita e falta de espaço presumida para a erupção dos dentes permanentes.

O prognóstico nesses pacientes é incerto e são necessárias observações periódicas, com o objetivo de avaliar a efetividade da terapia ortodôntica a ser instituída. Essas reavaliações é que darão ou não subsídios para a manutenção do tratamento ortodôntico conservador. Em casos onde o crescimento limita a terapia, pode ser razoável adotar
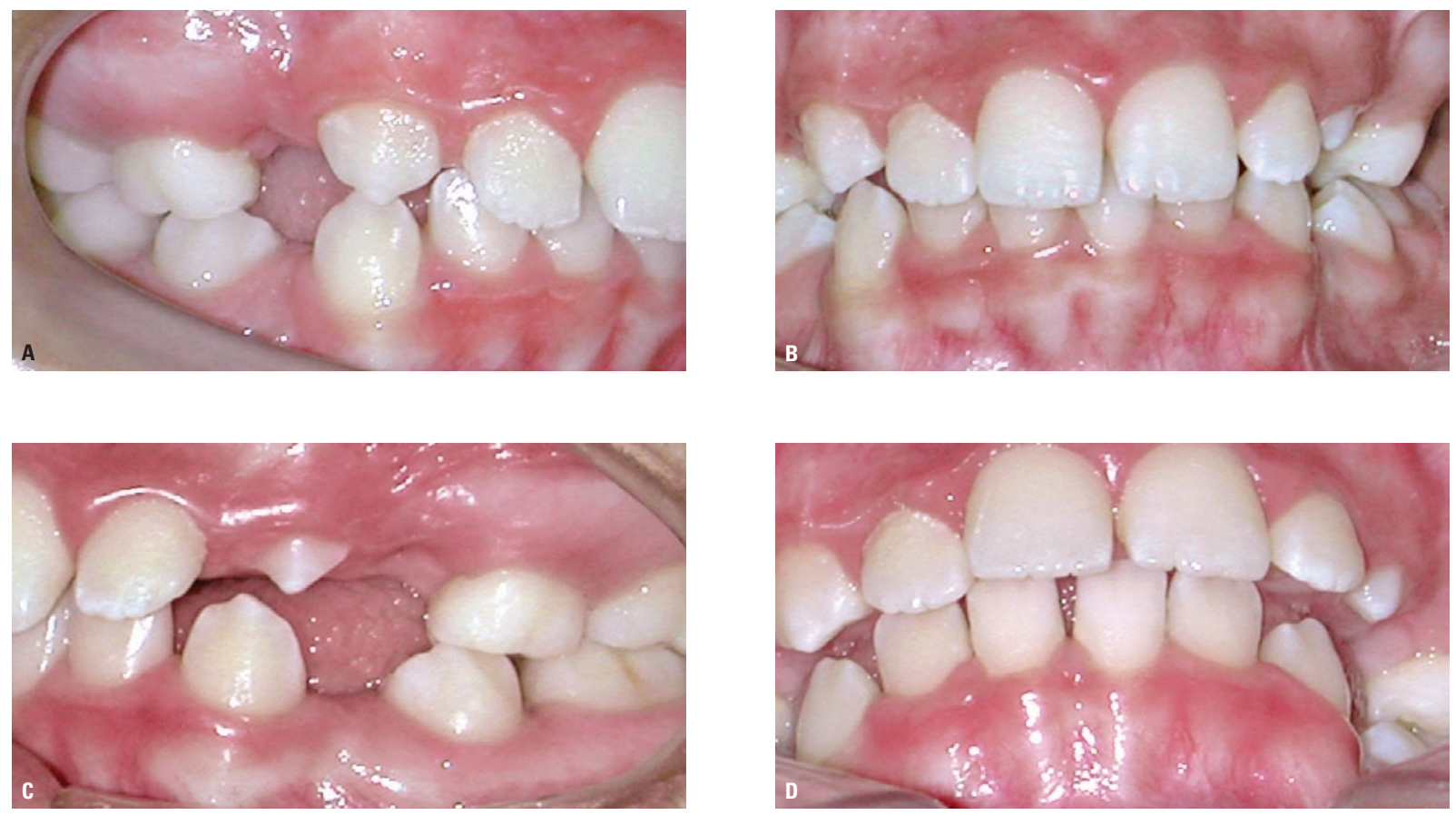

FIGURA 9 - Fotografias intrabucais depois de realizadas as exodontias dos primeiros pré-molares superiores e inferiores, com a intenção de diminuição do volume bucal e favorecimento da erupção dos caninos permanentes em seu "locu".

um procedimento cirúrgico como complemento ao tratamento ortodôntico.

O plano de tratamento deve obedecer regras que permitam construir uma boa oclusão, com ações compativeis com o padrão de crescimento que, se acredita, estará presente como fator condicionante. Essa regra poderia ser sintetizada em preservar ou diminuir o volume intrabucal.

$\mathrm{Na}$ paciente em questão, principalmente admitindo-se sua classificação como subtipo médio e a indicação com sucesso muito provável de um tratamento conservador, o plano de tratamento foi definido com a intenção de exercer algum controle sobre o componente vertical do crescimento facial e diminuição do volume bucal. Foram previstas e realizadas exodontias dos primeiros pré-molares superiores e inferiores, imediatamente após sua erupção, favorecendo a erupção dos caninos permanentes em seu "locu" (Fig. 9).

A exposição exagerada dos incisivos superiores,

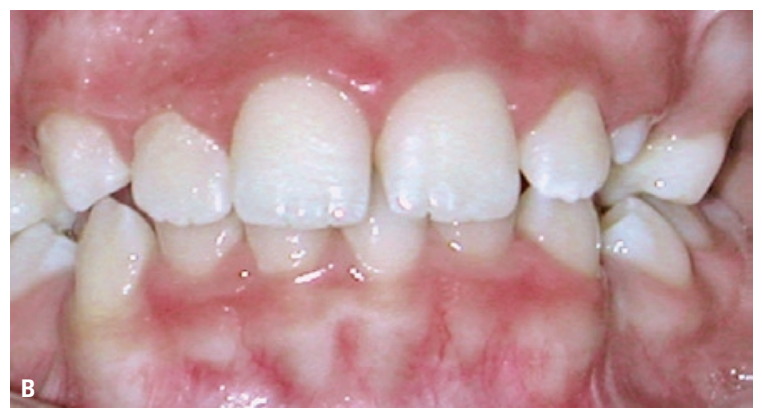

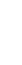


mesmo quando descontado o erro de postura do lábio superior, justificou a adoção de uma mecânica de intrusão dos incisivos superiores, iniciada aos 10 anos e 6 meses, imediatamente após a exodontia dos primeiros pré-molares. $\mathrm{Na}$ época do tratamento, os dispositivos para ancoragem absoluta (miniplacas e miniparafusos) ainda não estavam disponíveis no mercado. Dessa forma, como ancoragem, foram bandados os primeiros molares superiores com tubos triplos, seguidos de moldagem para trabalho, para confecção de barra transpalatina com looping invertido (para mesial) e mais afastada do palato (Fig. 10A, B, C). Cumprindo outro objetivo primário do tratamento, a restrição ao crescimento vertical da maxila, um aparelho extrabucal com tração média-alta em casquete de Interlan-
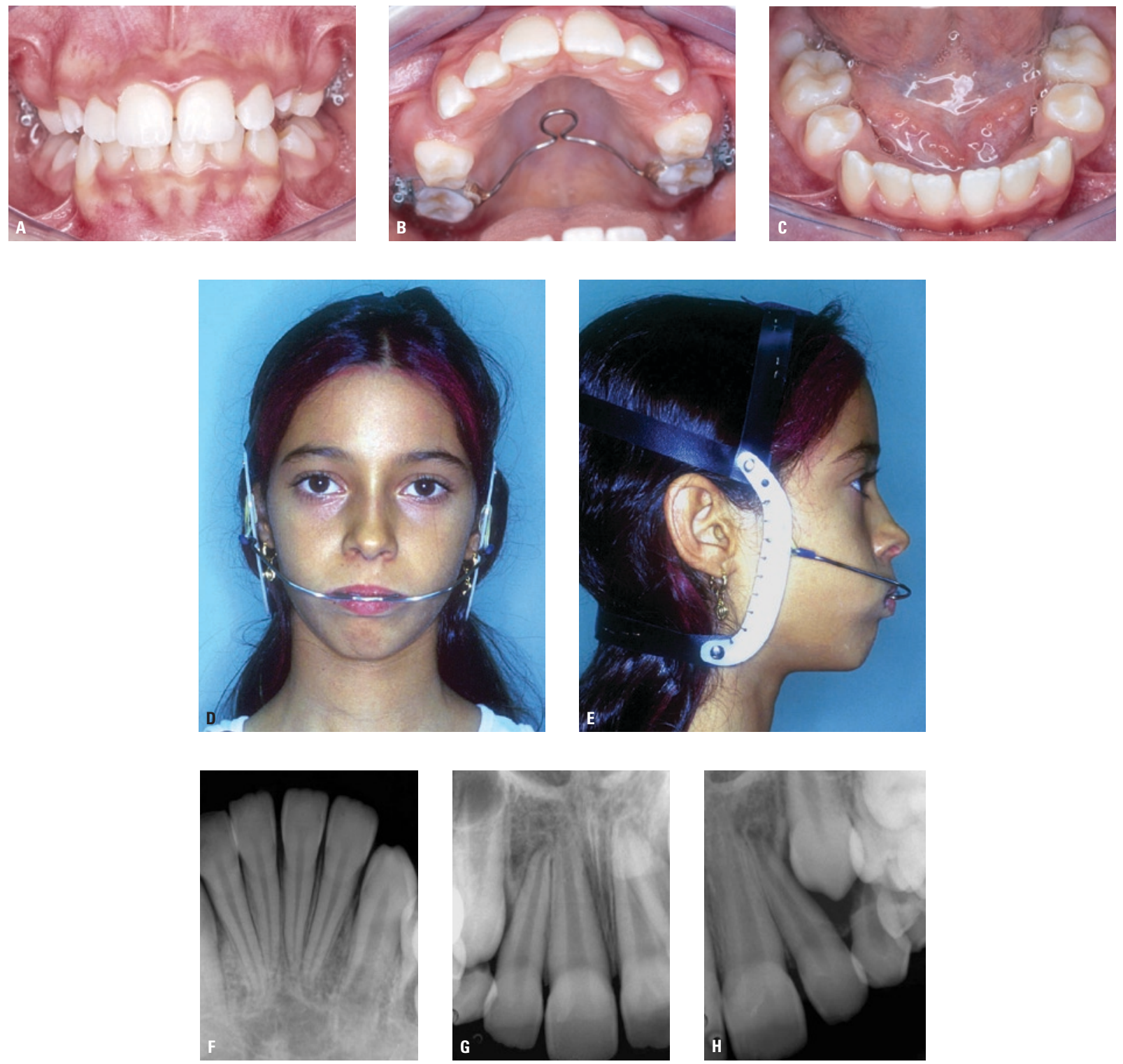

FIGURA 10 - Início da mecânica de intrusão dos incisivos superiores, aos 10 anos e 6 meses, com bandagem dos primeiros molares superiores com tubos triplos para confecção de barra transpalatina com looping invertido (para mesial) e mais afastada do palato (A-C). Um aparelho extrabucal com tração média-alta em casquete de Interlandi foi instalado, com a intenção de restrição ao crescimento vertical da maxila, para uso noturno (D-E). Radiografias periapicais iniciais de incisivos superiores e inferiores, pela Técnica do Paralelismo, foram requisitadas, como parâmetro para a mensuração dos custos biológicos relativos à mecânica intrusiva (F-H). 
di foi instalado. Foi recomendado à paciente fazer uso noturno do aparelho, durante 8 a 10 horas (Fig. 10D, E). O número reduzido de horas deve-se à intenção de otimizar os efeitos esqueléticos, em relação aos efeitos dentários, auxiliando na mecânica de ancoragem dos primeiros molares. Nesta mecânica, torna-se de extrema importância o controle radiográfico periódico, na intenção de quantificar os custos biológicos, normalmente maiores, relacionados a movimentos intrusivos ${ }^{12}$ (Fig. 10F).

Retomando a descrição do tratamento para intrusão dos incisivos superiores, estes foram colados com braquetes Edgewise convencional sem angulação, adaptando-se um fio retangular 0,019” x 0,025” de aço de forma passiva, com as dobras necessárias para tal, nas canaletas dos braquetes. Para reforço de ancoragem, os segundos molares decíduos foram incluídos em um segmento de fio retangular
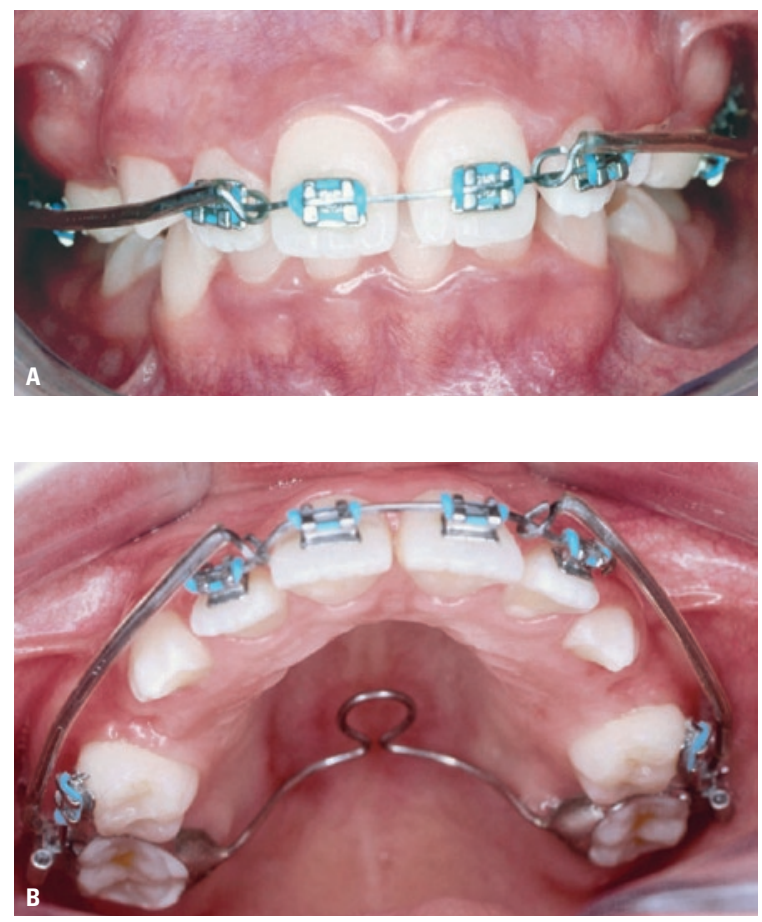

FIGURA 11 - 0s incisivos superiores, assim como os segundos molares decíduos, foram colados, e segmentos de fios retangulares $0,019^{\prime \prime} \times 0,025^{\prime \prime}$ de aço foram adaptados de forma passiva na região anterior e posterior. Braços de alavanca com fio retangular 0,019" x 0,025" Titânio-Molibdênio foram adaptados aos tubos auxiliares nos molares permanentes, com uma força para intrusão de $15 \mathrm{cN}$ por elemento dentário. passivo, que os unia aos primeiros molares permanentes. Braços de alavanca foram então confeccionados com fio retangular 0,019 " x 0,025" TitânioMolibdênio (TMA, Abzil Produtos Ortodônticos - catalog number. 502-777) e adaptados aos tubos auxiliares nos molares permanentes, sendo ativados para intruir os incisivos, com uma força de $15 \mathrm{cN}$ por elemento dentário (Fig. 11A, B).

A duração desta primeira fase do tratamento foi de 10 meses, interrompendo-se a mecânica de intrusão após esse período (Fig. 12A, B). Os custos biológicos da mecânica de intrusão foram
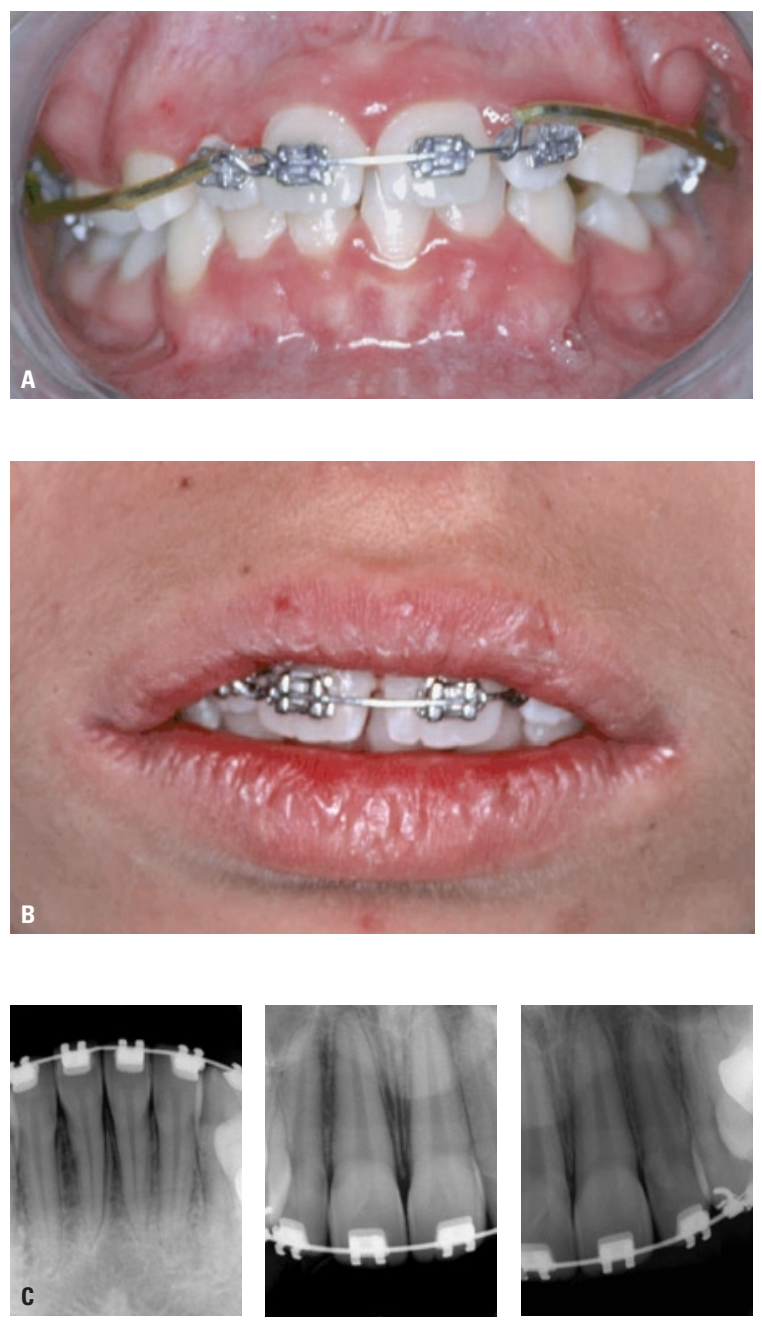

FIGURA 12 - Após 10 meses de mecânica intrusiva, os resultados para oclusão (A) e relação dos incisivos superiores com o lábio superior (B) foram razoáveis, sendo esta mecânica suspensa após este período. Os custos biológicos, mensurados nas radiografias periapicais controle (C), foram aceitáveis. 
aceitáveis (Fig. 12C). Após a erupção dos dentes permanentes, foi iniciada a segunda fase do tratamento ortodôntico corretivo, aos 11 anos e 4 meses. A barra transpalatina, assim como o AEB tração alta, foi mantida durante o período em que a erupção dos dentes permanentes era aguardada e também na fase inicial de alinhamento e nivelamento dos arcos dentários.

Foi dispensada uma atenção especial ao arco superior, durante toda a seqüência do tratamento corretivo. Como a mecânica de intrusão sobrecorrigiu os incisivos superiores, foram necessários degraus de intrusão à distal dos incisivos laterais, desde as fases iniciais do nivelamento até o final do tratamento. A barra transpalatina foi suspensa previamente à colocação do arco superior retangular 0,019" x 0,025" de aço.
Nessa fase, com a forma corrigida e a possibilidade de adquirir função, a paciente foi encaminhada para avaliação e orientação com uma fonoaudióloga especializada em motricidade oral.

Radiografias foram, então, requisitadas, para avaliação do tratamento e orientação na finalização (Fig. 13A, B, C). A radiografia panorâmica (Fig. 13A) mostrou bom posicionamento das raízes - exceto dos dentes 15 e 25 , que receberam dobras para correção - e preservação apical das raízes. As radiografias periapicais (Fig. 13B) confirmaram essa preservação, inclusive dos incisivos superiores, que foram submetidos à intrusão, um movimento que predisporia a reabsorção.

O tratamento ortodôntico corretivo, relativo à fase de aparelhos fixos, foi finalizado após 16 meses (Fig. 14A-E). Os resultados do trata-
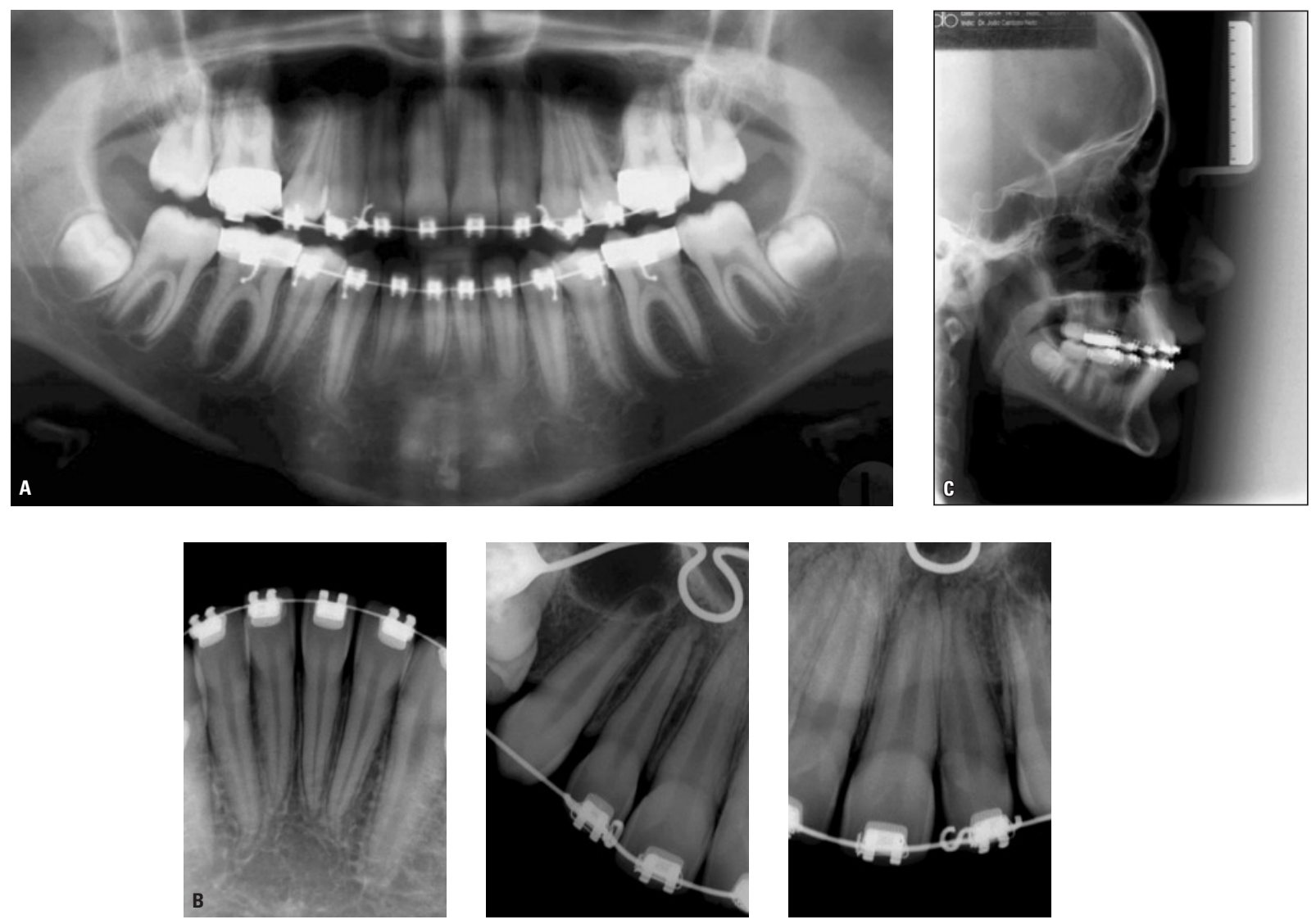

FIGURA 13 - A radiografia panorâmica final (A) mostrou bom posicionamento das raízes, exceto dos dentes 15 e 25 , que receberam dobras para correção. As radiografias periapicais finais de incisivos superiores e inferiores (B) confirmaram preservação nos ápices radiculares. A radiografia lateral da face (C) evidenciou a correção ortodôntica introduzida, com uma melhora da relação entre os incisivos superiores e o lábio superior. 

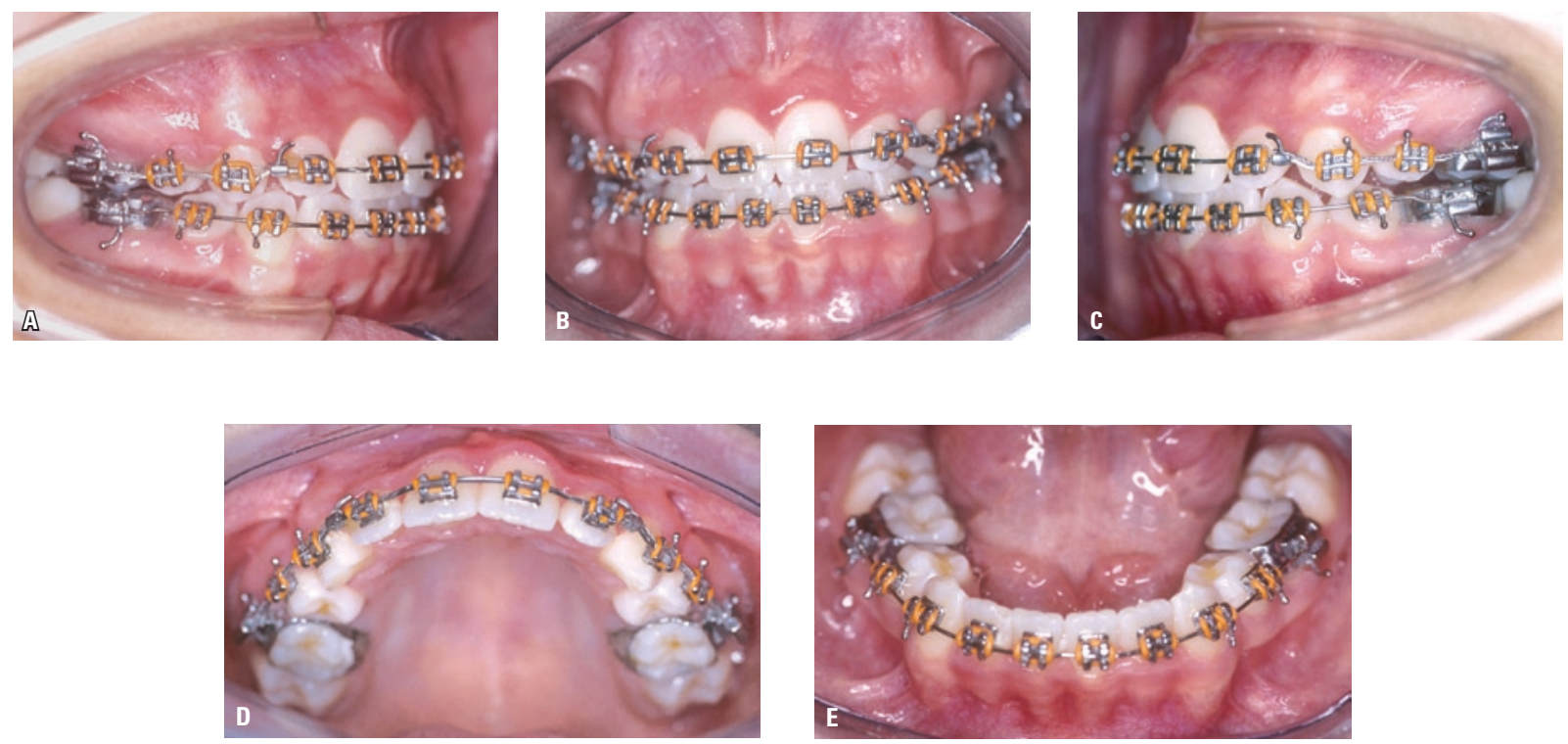

FIGURA 14 - 0 tratamento ortodôntico corretivo, relativo à fase de aparelhos fixos, foi finalizado após 16 meses. 0s resultados do tratamento foram bastante razoáveis para a oclusão.

mento foram bastante razoáveis para a oclusão, conforme evidenciado pelas fotografias obtidas um mês após a remoção dos aparelhos (Fig. 15A-E). A paciente, então com idade de 12 anos e 10 meses, apresentava aparência facial mais adequada, evidenciando-se a eficiência corretiva do tratamento efetuado, especialmente para as relações de nariz, lábio superior e incisivos superiores com a face, mesmo admitindo-se hipotonia na musculatura peribucal (Fig. 15F-H). Contenções 3x3 e Placa de Hawley foram utilizadas, esta última com uma perfuração na região da papila incisiva, por solicitação da fonoaudióloga (Fig. 15I).

No controle de 2 anos e 10 meses, a paciente com 16 anos de idade, ao final do crescimento, apresentou manutenção da correção introduzida com o tratamento ortodôntico. As relações oclusais estavam boas (Fig. 16A-E) e foi dada atenção aos terceiros molares inferiores, que apresentavam chance de irromper, tendo sido acompanhados para definição de conduta conservativa ou necessidade de extração (Fig. 16F).
A face não melhorou, frustrando a sensação de que os lábios poderiam cobrir a distância que os separava, dentro de uma altura facial anterior inferior que parecia normal (Fig. 16G-J). Talvez, com o tempo, a maturação e o envelhecimento tornem-a melhor.

De qualquer modo, em uma perspectiva realista do que seja possível obter com um tratamento ortodôntico, de acordo com as regras para os indivíduos do Padrão Face Longa de severidade média, os resultados podem ser considerados bons. A estabilidade deve ser creditada ao respeito adotado para com as limitações de forma, inerentes ao padrão de crescimento e à introdução gradativa das correções, que foram - exceto o manejo para trás e para cima dos incisivos superiores - consistentes com as necessidades compensatórias desse indivíduo. Além disso, não devem ser desprezados os esforços realizados para melhorar a função respiratória e a motricidade peribucal, justificando-se o manejo interdisciplinar que deve ser inerente ao tratamento dessas más oclusões. 

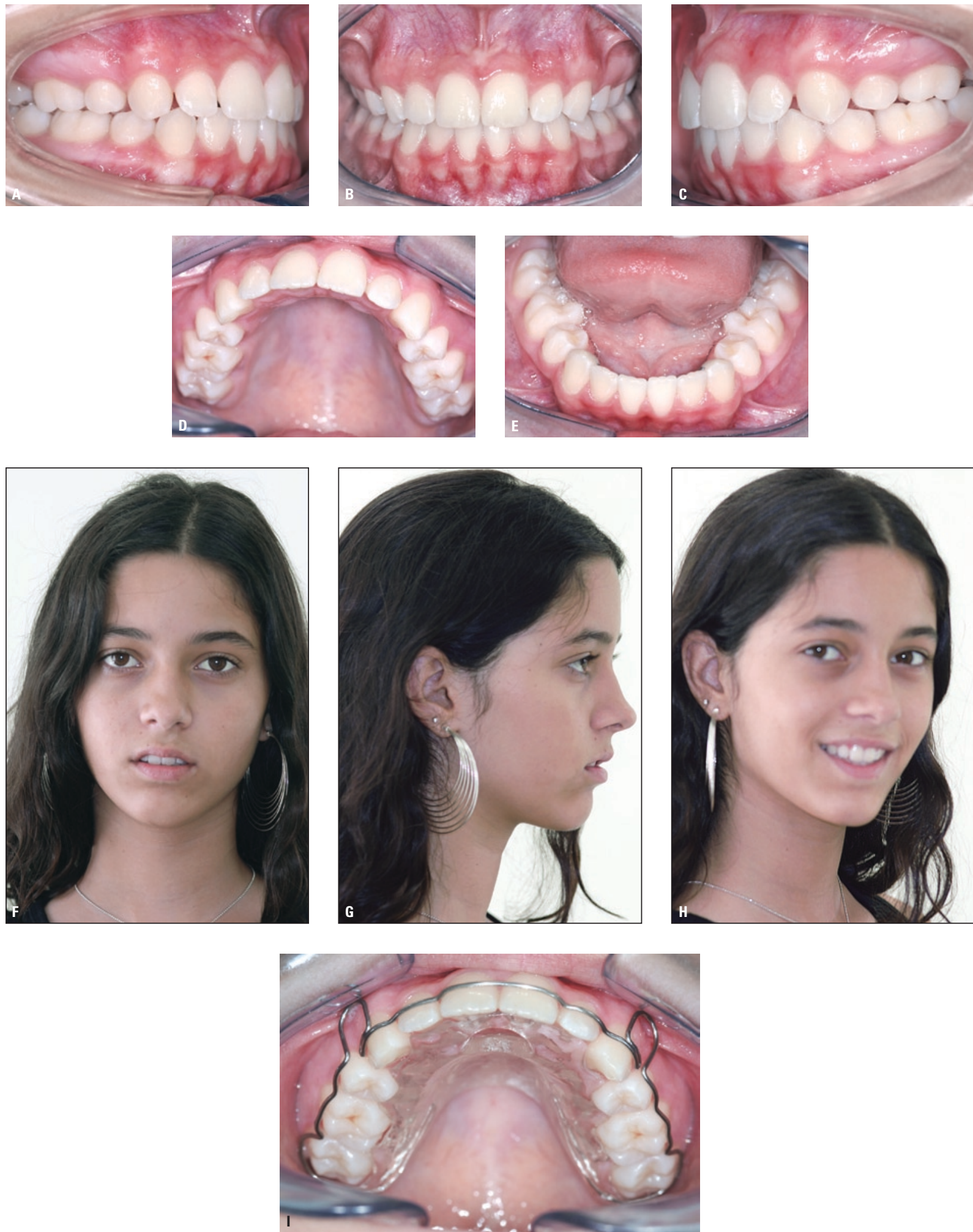

FIGURA 15 - Oclusão (A-E) e face (F-H) um mês após a remoção dos aparelhos. A paciente, aos 12 anos e 10 meses, apresentava aparência facial mais adequada, evidenciando-se a eficiência corretiva do tratamento efetuado. Na placa de Hawley, foi realizada uma perfuração na região da papila incisiva, por solicitação da fonoaudióloga (I). 

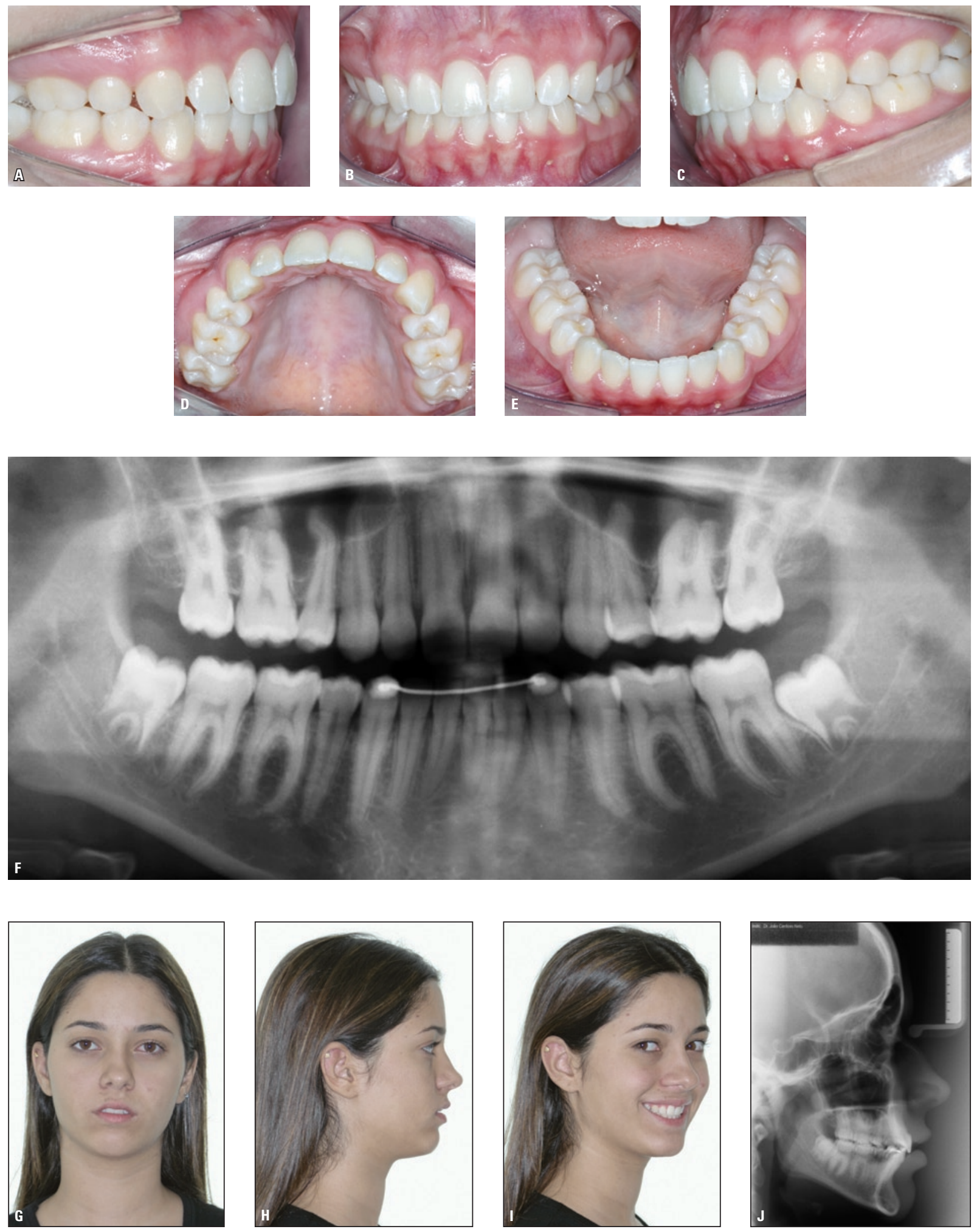

FIGURA 16 - Face e oclusão aos 16 anos de idade, 2 anos e 10 meses após a remoção dos aparelhos. As relações oclusais estavam boas (A-E) e foi dada atenção aos terceiros molares inferiores, que apresentavam chance de irromper (F). A face não melhorou (G-I), frustrando a sensação de que os lábios poderiam cobrir a distância que os separava, dentro de uma altura facial anterior inferior que parecia normal, confirmada na radiografia lateral da face (J). 


\section{Padrão Face longa subtipo severo}

O paciente apresentado a seguir exemplifica o manejo de um Padrão Face Longa subtipo severo (Fig. 17). O paciente apresentava 12 anos e 5 meses no momento da consulta e o motivo da avaliação era a preocupação dos pais em relação ao padrão de crescimento. Afinal existia na história familiar a necessidade de cirurgia ortognática, uma vez que a mãe e um tio do paciente já ha- viam sido submetidos a tratamento ortodôntico e cirurgia ortognática. Tais informações, certamente, impressionaram o prognóstico do caso.

$\mathrm{Na}$ análise frontal (Fig. 17A), era perceptível apenas um sutil comprometimento, com prejuízo da expressão facial, devido à ausência da projeção zigomática, além de um desvio do mento para o lado esquerdo, causado por provável laterognatismo. O perfil facial já estava mais afetado (Fig. 17B),
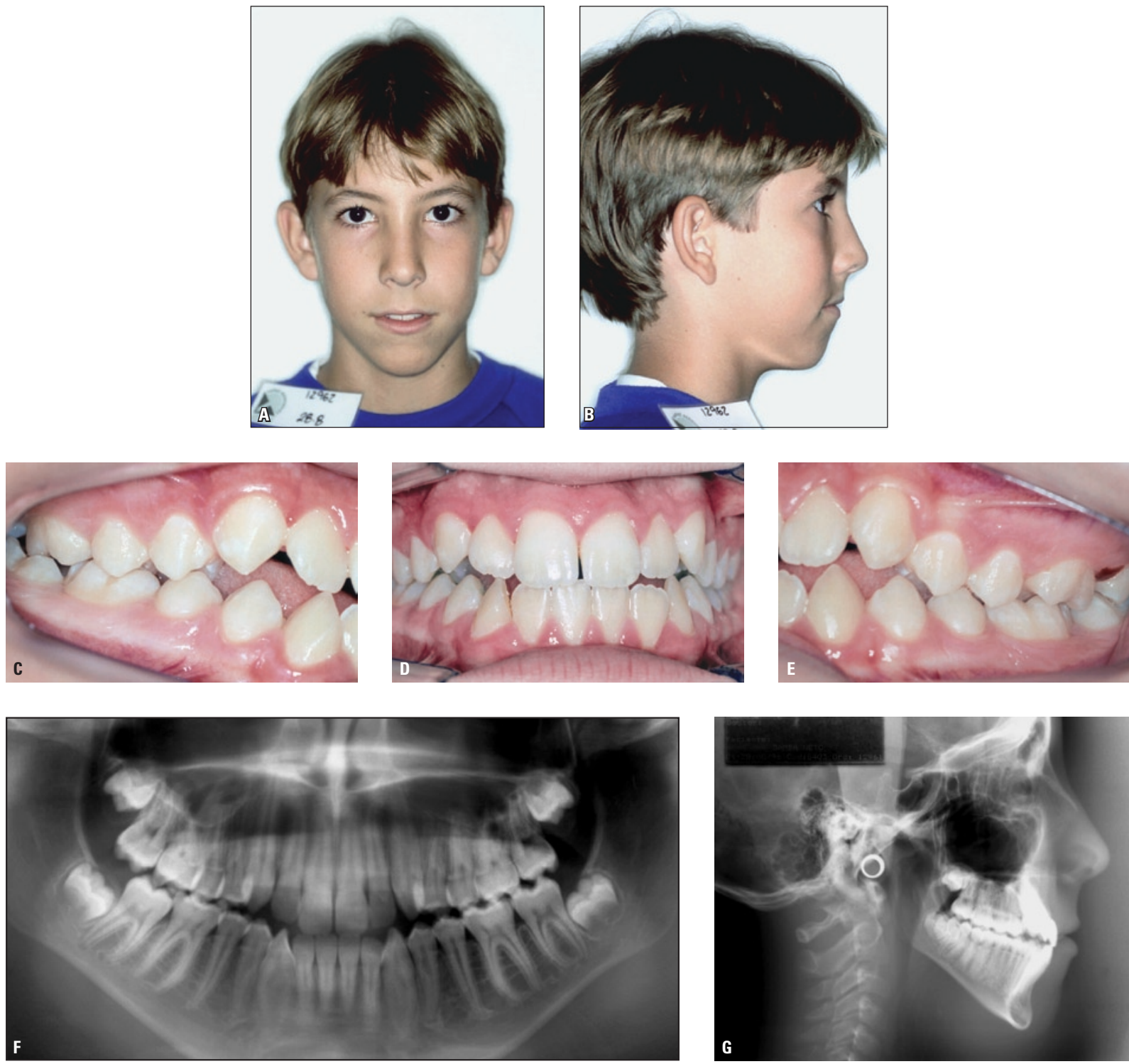

FIGURA 17 - Face (A-B), oclusão (C-E) e radiografias iniciais (F-G) de um paciente face longa subtipo severo, aos 12 anos e 5 meses, no qual a estética facial encontrava-se comprometida desde as fases mais precoces do desenvolvimento. Um crescimento horizontal de côndilo, com uma conseqüente rotação horária da mandíbula, além de uma desproporção entre ramo e corpo mandibular, foram observados (G). 
confirmando o envolvimento zigomático, com uma linha queixo-pescoço curta e uma forte convexidade do terço inferior da face, claramente retrognática. A estética facial, comprometida desde as fases mais precoces do desenvolvimento, deveria piorar muito com o crescimento, até atingir o final do surto, se o diagnóstico se confirmasse.

$\mathrm{Na}$ avaliação clínica da oclusão, uma relação de topo dos incisivos pôde ser observada na dentadura permanente completa, com relação de Classe III lado direito (3/4) e (1/4) no lado esquerdo, com desvio da linha média inferior para a esquerda. Uma mordida aberta anterior na região de caninos também foi observada, com trespasse vertical justo na região de incisivos centrais (Fig. 17C-F). Vale ressaltar que o paciente já havia se submetido a tratamento ortopédico durante três anos e seis meses, com aparelho removível para correção da Classe III e mentoneira. Nesta fase, não havia queixa estética, com relação à face, por parte do paciente.

A documentação solicitada contribuiu para um melhor entendimento das características da má oclusão. O padrão de crescimento desfavorável pôde ser confirmado por meio da avaliação da morfologia, na radiografia lateral da face. Um crescimento horizontal de côndilo, com uma conseqüente rotação horária da mandíbula, além de uma desproporção entre o ramo e o corpo mandibulares, foram observados (Fig. 17G). A mandíbula, enorme, parecia pequena na face, devido ao crescimento predominante em direção caudal. A maxila tinha pouca participação na construção dessa face longa severa, com uma posição razoável do plano palatino, e não havia excesso considerável na distância dos ápices dos molares superiores ao plano palatino. Já havia, nessa idade, uma extrusão dos incisivos inferiores, característica desses pacientes, alongando a região do mento. Além disso, os incisivos superiores e inferiores se encontravam posicionados em exígua área óssea na maxila e mandíbula, podendo se dizer que eles estavam onde poderiam estar. Isso, em outras palavras, re- presentava sérias limitações à sua movimentação em abordagens ortodônticas ${ }^{26}$.

A compilação dos exames da morfologia facial, da radiografia e da análise da oclusão confirmou o diagnóstico de má oclusão do Padrão Face Longa subtipo severo. Os responsáveis foram avisados e devidamente orientados quanto à limitação da abordagem ortodôntica e da grande possibilidade de intervenção cirúrgica ao final do surto de crescimento, caso esse processo se manifestasse de acordo com o diagnóstico elaborado.

Pacientes desse tipo devem ser encaminhados para uma consulta com um cirurgião bucomaxilofacial da confiança do ortodontista ou dos pais, especialmente no que concerne orientações sobre custos financeiros e riscos aos quais estarão expostos com esse procedimento.

Nesses casos, um procedimento interceptativo ortopédico é inócuo, considerando-se a desagradabilidade das relações faciais do paciente. Isso não significa, entretanto, que devam retornar ao consultório somente após o término do crescimento: o período entre o exame inicial e a confirmação de um subtipo severo deve privilegiar a erupção dentária e manter o paciente e seus familiares cientes da evolução, a cada passo, e das possibilidades de correção plena da face e dentes, ao final do crescimento.

Neste paciente, especificamente, já se observava, no exame inicial, a dentadura permanente completa até primeiros molares, demandando apenas um monitoramento de crescimento assistido.

A grande dificuldade para o profissional, nesses casos, é persuadir o jovem paciente de que a espera é a única conduta terapêutica adequada no momento, uma vez que ele se encontra em fase de convívio na sociedade particularmente dependente de sua aparência física. Torna-se difícil para o paciente assimilar a necessidade de permanecer com o erro facial, que normalmente é a queixa, até o final do crescimento ativo. Neste caso, a impossibilidade de atitudes terapêuticas conservadoras, devido à severidade do caso, era clara.

Exatamente nesse aspecto é que se identifica 
a grande importância da classificação por subtipos, considerando-se a severidade. Neste caso particular, o prognóstico seria indiscutivelmente ruim ao término do crescimento.

Grande parte dos insucessos dos tratamentos ortodônticos conservadores é gerada por atitudes terapêuticas inócuas, em indivíduos com essas características, justamente por não se determinar um prognóstico adequado.

Uma nova documentação ortodôntica foi requisitada três anos e dez meses após a consulta inicial, com a finalidade de acompanhar o crescimento e confirmar a hipótese cirúrgica aventa- da no primeiro controle (Fig. 18). Nesta fase, o paciente encontrava-se com 16 anos e 3 meses, com um padrão de crescimento facial visivelmente perturbado (Fig. 18A, B, C), provavelmente agravado pela remoção da mecanoterapia compressiva na mandíbula, uma vez que, durante esse período, o paciente esteve livre para expressar o potencial de crescimento determinado por sua genética. Os responsáveis estavam preocupados com a deterioração das relações dentárias, com a diminuição do trespasse vertical e o aumento do apinhamento em ambos os arcos. Isso pôde ser confirmado na avaliação da teler-
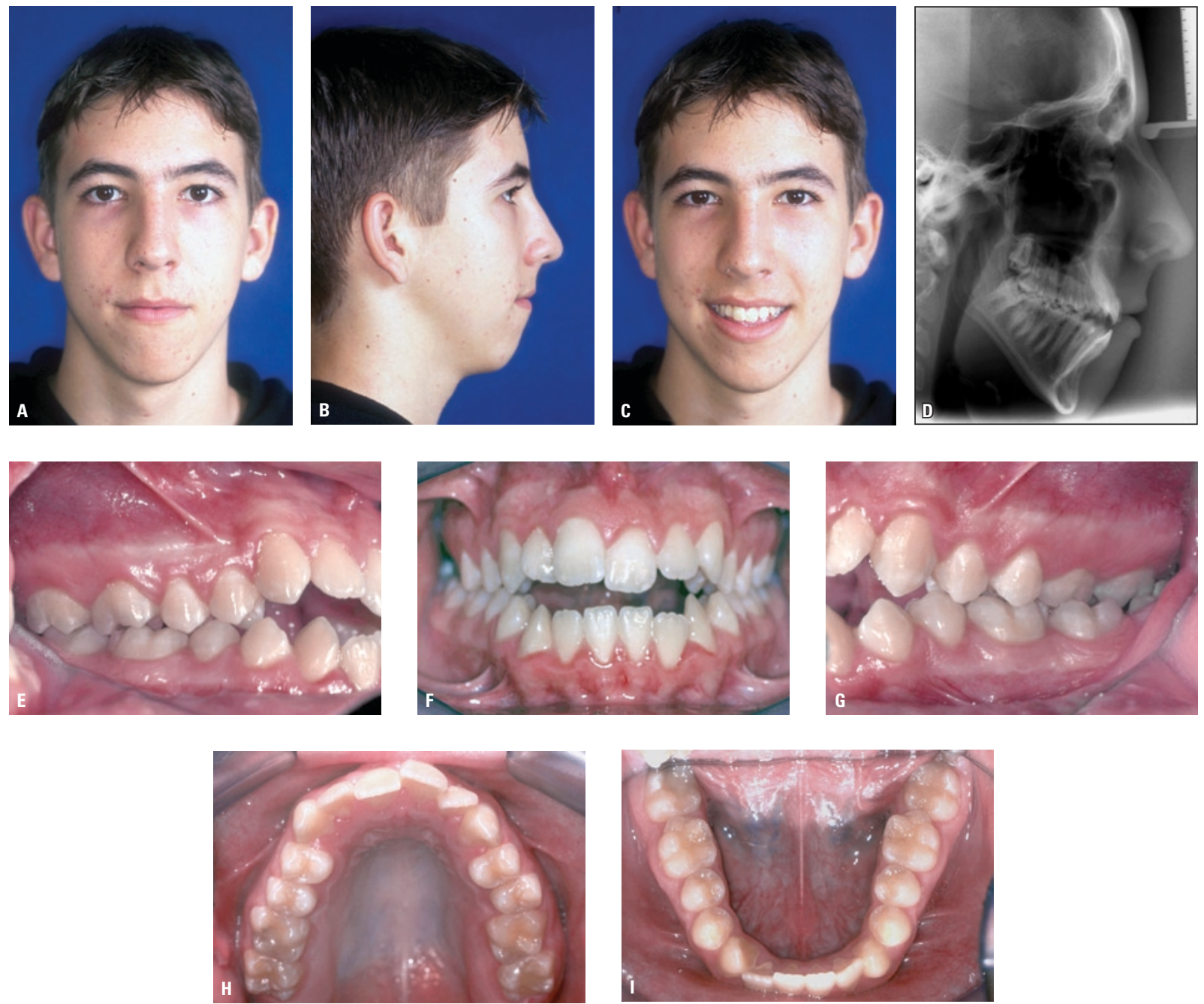

FIGURA 18 - Face (A-C), radiografia lateral da face (D) e oclusão (E-I) três anos e dez meses após o diagnóstico inicial de face longa subtipo severo. Nesta fase, o paciente encontrava-se com 16 anos e 3 meses, com um padrão de crescimento facial visivelmente perturbado (A-C), sendo o agravamento da doença confirmado nas avaliações da telerradiografia (D) e oclusão (E-I). 
radiografia (Fig. 18D), observando-se que a rotação mandibular provocada pelo crescimento horizontal de côndilo, com conseqüente abertura do ângulo goníaco, assim como o excesso vertical na região da sínfise, foram magnificados.

As relações oclusais também foram agravadas nesse período. A relação oclusal do lado esquerdo era de Classe III total, mantendo-se o lado direito em Classe I. O desvio da linha média inferior para esquerda foi agravado, com mordida cruzada do dente 16 (Fig. 18E-G). Um trespasse horizontal negativo foi observado, com mordida aberta anterior de canino a canino, mais grave na região dos incisivos centrais, além das restrições ao comprimento dos arcos dentários, com forte apinhamento em ambos os $\operatorname{arcos}$ (Fig. 18H, I).

Novas orientações foram dadas aos responsáveis, com o objetivo de consolidar o diagnóstico inicial. Nessa fase, o paciente ainda não apresentava os sinais de pubescência, não havendo, portanto, a necessidade da requisição de radiografia carpal para avaliação. Recomendou-se ao paciente e seus responsáveis que retornassem ao consultório a cada seis meses, até o final do surto de crescimento.

Cinco anos e oito meses depois da consulta inicial, foi requisitada uma nova documentação ortodôntica ao paciente, após comprovação do estágio final de crescimento. Essa documentação foi avaliada observando-se o processo de fusionamento da epífise e diáfise do rádio, de acordo com Hagg e Taranger ${ }^{25}$ (Fig. 19). O paciente, com idade de 18 anos e 1 mês, encontrava-se em estágio IJ, estágio final de capeamento, estando indicado, portanto, o início da mecânica ortodôntica descompensatória, com finalidade de preparo para cirurgia ortognática. Nesse estágio, após análise da documentação (Fig. 20) e plano de tratamento ortodôntico, o paciente foi novamente encaminhado para avaliação com o cirurgião. Entende-se que essa interação, entre cirurgião bucomaxilofacial e ortodontista, é de

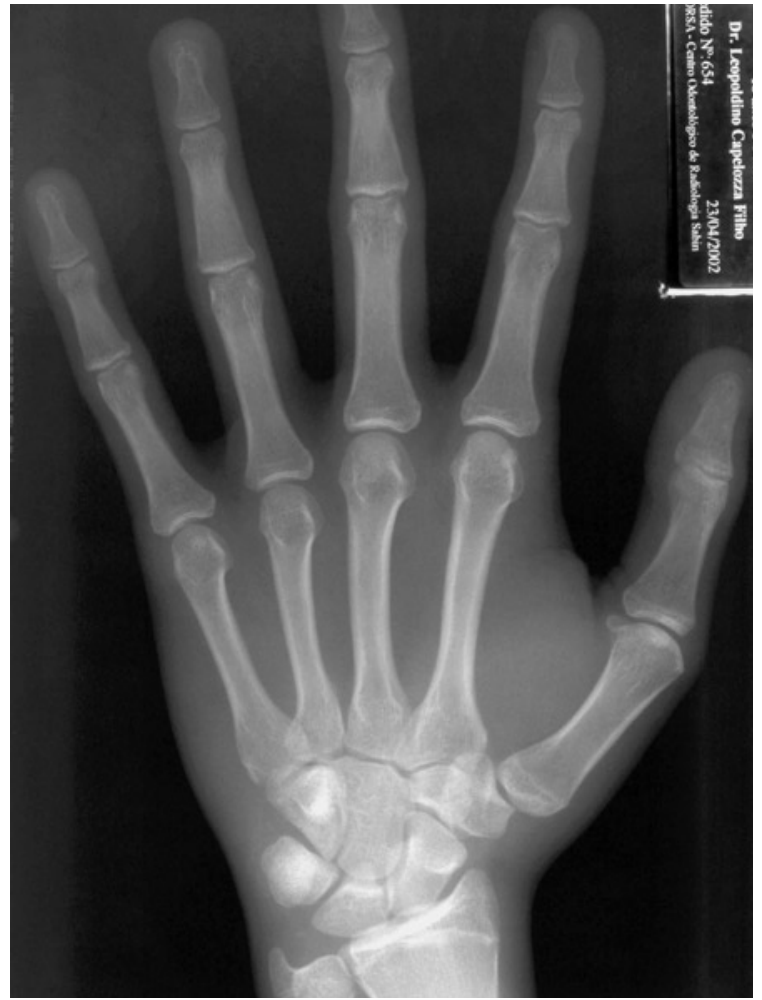

FIGURA 19 - A comprovação do estágio final de crescimento pôde ser observada por meio do fusionamento, que encontrava-se em estágio IJ, estágio final de capeamento da epífise e diáfise do rádio, de acordo com Hagg e Taranger ${ }^{25}$.

fundamental importância na definição de um diagnóstico e do plano de tratamento adequado para o paciente.

O planejamento ortodôntico consistiu, basicamente, no alinhamento e nivelamento dos arcos dentários, evitando-se grandes movimentos. $\mathrm{O}$ apinhamento era significativo, mas a tendência minimalista para movimentação nos pacientes Padrão Face Longa suportou a indicação de desgaste nas superfícies interproximais, de mesial a mesial dos primeiros pré-molares superiores e inferiores.

O tratamento iniciou-se pelo arco inferior, com alinhamento e nivelamento, aceitando-se moderada protrusão, associado a um desgaste mais concentrado na mesial de pré-molares e distal de caninos, objetivando a eliminação da discrepância dentária, que era de aproximada- 

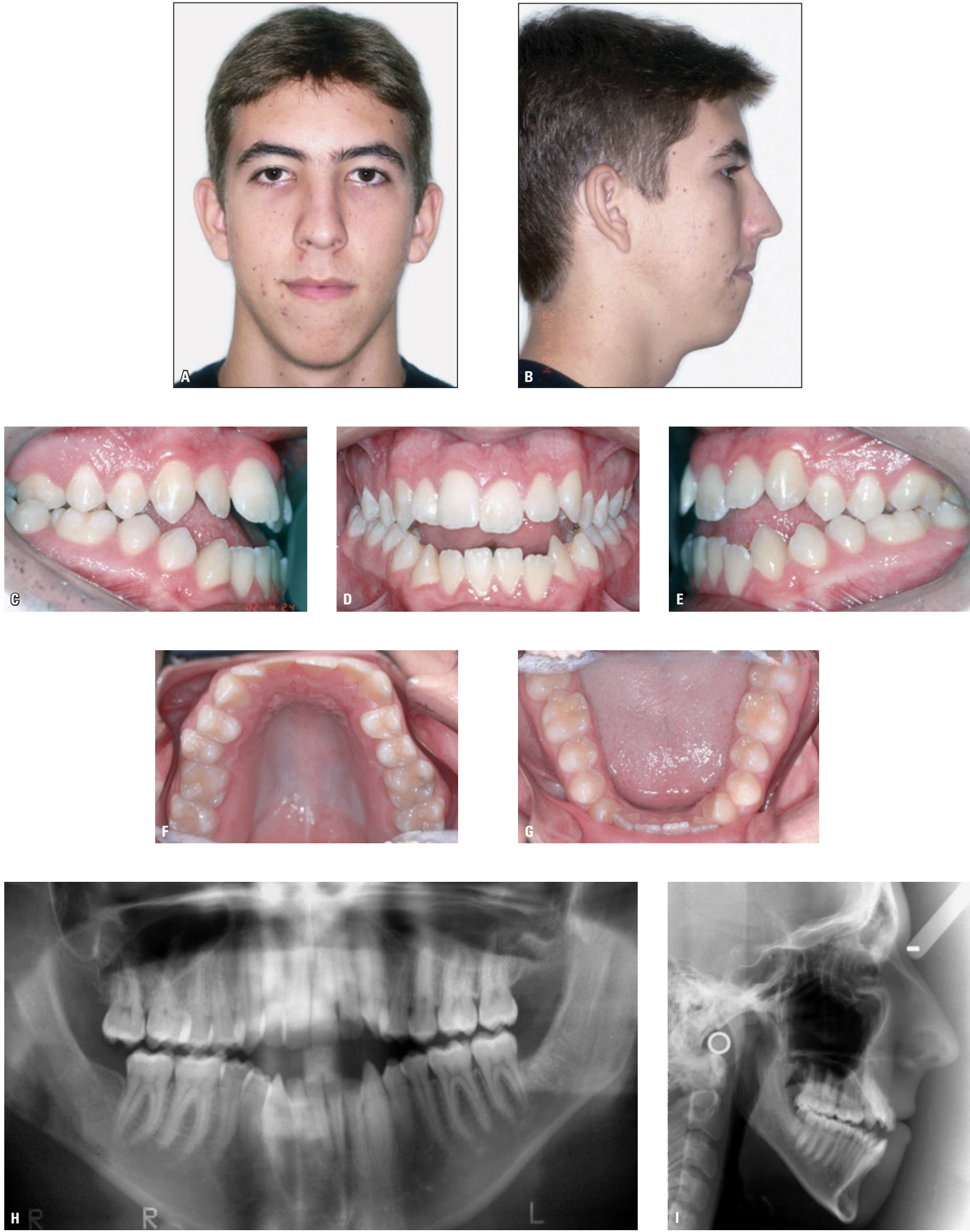

FIGURA 20 - Face (A-B), oclusão (C-G) e radiografias iniciais (H-I) do paciente aos 18 anos e 1 mês, 5 anos e 8 meses depois do diagnóstico inicial, estando indicado, portanto, o início da mecânica ortodôntica descompensatória com finalidade de preparo para cirurgia ortognática. Nesse estágio, o paciente foi novamente encaminhado para avaliação com o cirurgião. 
mente $5 \mathrm{~mm}$. Essa ação foi potencializada por meio de alças na mesial dos primeiros molares inferiores (Fig. 21).

É importante ressaltar que, no tratamento cirúrgico descompensatório, uma das metas é remover a camuflagem da má oclusão, posicionando-se os dentes o mais próximo do ideal em suas bases ósseas, de modo que a má oclusão fique explícita, para que o cirurgião possa atuar bem. Isso implica que, antes do procedimento cirúrgico, as relações faciais e oclusais sejam agravadas, sendo de grande importância para o paciente e seus responsáveis a elucidação dessas condições, necessárias para o procedimento cirúrgico.

Nos pacientes Padrão Face Longa, como já visto, os incisivos geralmente estão onde podem estar e, portanto, há muita limitação para mudar esses dentes de lugar ${ }^{10,13,14}$. Essa limitação não chega a ter significância no resultado do tratamento cirúrgico, porque a cirurgia nos pacien- tes desse padrão mobiliza maxila e mandíbula e executa movimentos rotacionais que permitem expressão máxima à correção das relações das bases ósseas.

No caso deste paciente, imediatamente após o início da mecânica no arco inferior, os primeiros molares permanentes superiores foram bandados e uma barra transpalatina ativa para expansão foi adaptada. Após a melhora na dimensão transversal do arco dentário superior, o aparelho fixo foi instalado. Como regra, os segundos molares superiores e inferiores devem ser sempre inclusos na mecânica descompensatória para preparo cirúrgico.

Como já visto para os incisivos inferiores, a vestibularização dos incisivos superiores deveria ser evitada e, com esse intuito, foi realizado desgaste na distal dos caninos e mesial dos primeiros pré-molares superiores e na mesial e distal dos incisivos superiores. A intenção manifesta
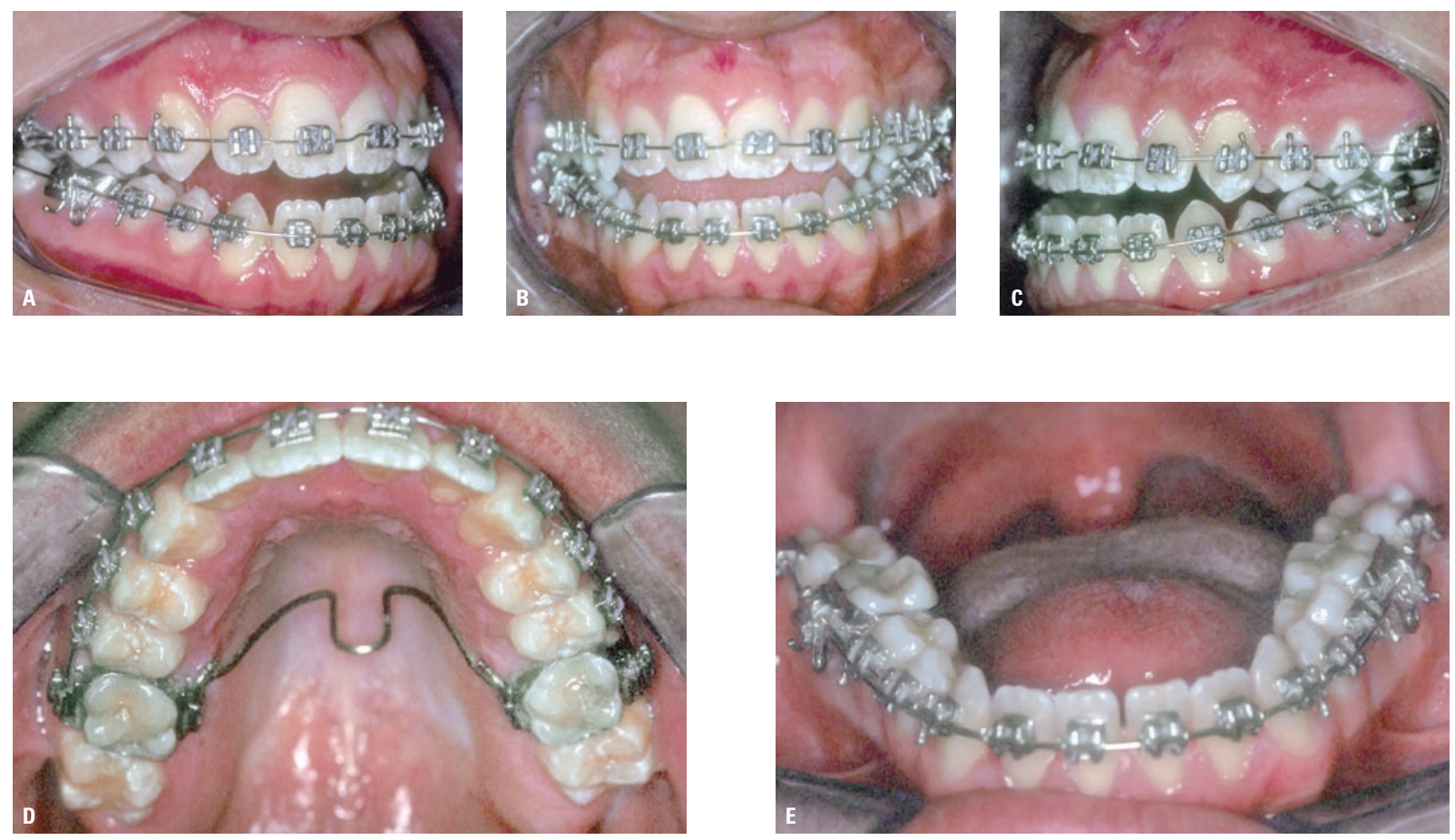

FIGURA 21- Mecânica ortodôntica corretiva com intenção descompensatória, aceitando-se moderada protrusão no arco inferior, associada a um desgaste mais concentrado na mesial de pré-molares e distal de caninos, objetivando a eliminação da discrepância dentária. Essa ação foi potencializada por meio de alças na mesial dos primeiros molares inferiores. 
neste procedimento era o ganho de espaço para o alinhamento e nivelamento do arco superior com reduzido efeito protrusivo.

Note-se que a forma do arco superior era relativamente boa e a atresia foi corrigida com a utilização de barra transpalatina. Uma expansão ortopédica ou cirúrgica do arco superior estaria contra-indicada, uma vez que não se observava uma atresia esquelética da maxila, com forma do arco adequada para um indivíduo dolicofacial, que é a meta terapêutica para essa face longa depois de corrigida.

A seqüência de nivelamento e alinhamento deve ser executada até os fios retangulares, fase na qual são realizadas as moldagens dos arcos dentários para estudo. Os modelos dos arcos dentários são, então, dinamicamente manipulados e as relações dentárias avaliadas na posição corrigida. Eventuais erros nessa relação são anotados e na próxima sessão clínica se inicia sua correção. Este procedimento deve ser observado para que o cirurgião possa finalizar a cirurgia com os arcos dentários em uma oclusão mais próxima da ideal, potencializando a estabilidade ao favorecer a função no pós-operatório.
Após a fase de preparo, especialmente nos pacientes portadores de Padrão Face Longa Classe III, a relação transversal dos arcos dentários parece insatisfatória. Esta "falsa atresia" é eliminada com a manipulação dinâmica dos modelos (Fig. 22). Ao se observar a relação oclusal Classe I bilateral e a linha média centralizada, o paciente está pronto para realizar a cirurgia ortognática. Nesta fase, após 19 meses de tratamento, os esporões foram soldados nos arcos retangulares e o paciente foi encaminhado para o cirurgião.

A cirurgia foi realizada quando o paciente tinha 19 anos e 9 meses de idade. Um procedimento cirúrgico combinado de maxila e mandíbula foi então realizado. Na maxila, uma osteotomia tipo Le Fort I foi realizada, para um movimento de avanço e impacção maxilar simultâneo; na mandíbula, uma osteotomia sagital oblíqua foi realizada, com objetivo de correção da forma por meio de rotação anti-horária - e correção do laterognatismo. Essas ações foram potencializadas com uma mentoplastia horizontal deslizante, para aumento da linha queixo-pescoço e diminuição da altura facial anterior inferior.
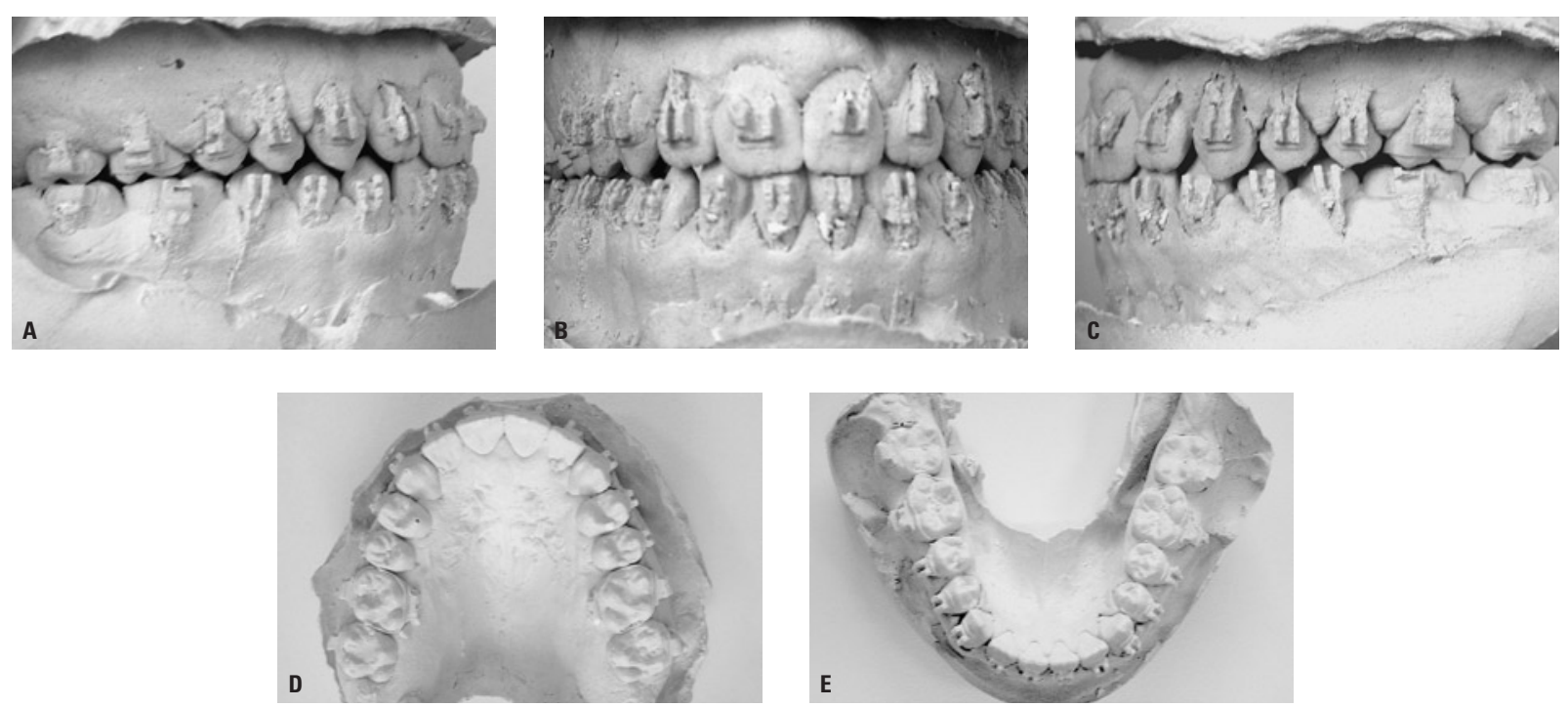

FIGURA 22 - Após 19 meses de tratamento descompensatório, uma relação oclusal Classe I bilateral e linha média centralizada foram obtidas na manipulação dinâmica dos modelos de estudo. 0 paciente, aos 19 anos e 9 meses de idade, encontrava-se apto para realizar a cirurgia ortognática. 
No pós-operatório de um mês, uma normalização nas relações faciais pôde ser observada, apesar do evidente, porém normal nesta fase, edema pós-operatório (Fig. 23).

Fica demonstrado que o grande "maestro" da correção nas discrepâncias esqueléticas é o cirurgião comaxilofacial. $O$ paciente retornou aos cuidados do ortodontista após 60 dias, para orientação de uso dos elásticos inter-maxilares e finalização ortodôntica.

A mecânica de elásticos deve estar sempre correlacionada ao procedimento cirúrgico executado, atuando na mesma direção que o movimento cirúrgico realizado. Nesta perspectiva, nos pacientes operados com objetivo de diminuição da altura facial, elásticos verticais não deveriam ser utilizados por longos períodos de tempo. Não obstante, esta mecânica deve ser suspensa de forma gradativa, com a realização de teste de estabilidade antes da remoção total.

A duração da fase de finalização pós-cirúrgica foi de seis meses, com evidente melhora das relações faciais, após a diminuição do edema pósoperatório, e oclusais (Fig. 24). Infelizmente, não se dispõe da documentação fotográfica e dos modelos dos arcos dentários ao final do tratamento. Embora solicitada, ela não foi feita pelo paciente. Os controles de pós-tratamento também não foram adequadamente cumpridos, por motivos de força maior, alegados pelo paciente. De qualquer modo, o primeiro controle que ele permitiu, aos 22 anos e 6 meses de idade, 2 anos e 3 meses após a remoção dos aparelhos, evidenciava uma enorme melhora facial e uma boa oclusão, especialmente se for considerado que o paciente não fez uso da contenção superior, a placa de Hawley (Fig. 25).

O paciente e seus responsáveis, após um longo período de acompanhamento, reconheceram a eficiência do plano de tratamento proposto. Isso evidencia claramente o acerto da opção pelo monitoramento de erupção e crescimento em indivíduos portadores de más oclusões do Padrão Face Longa, subtipo grave. Aguardando-se a oclusão e a face ficarem prontas, às expensas de um crescimento presumidamente inadequado, substitui-se longos, caros e infrutíferos tratamentos, por uma abordagem direta, eficiente e previsível.
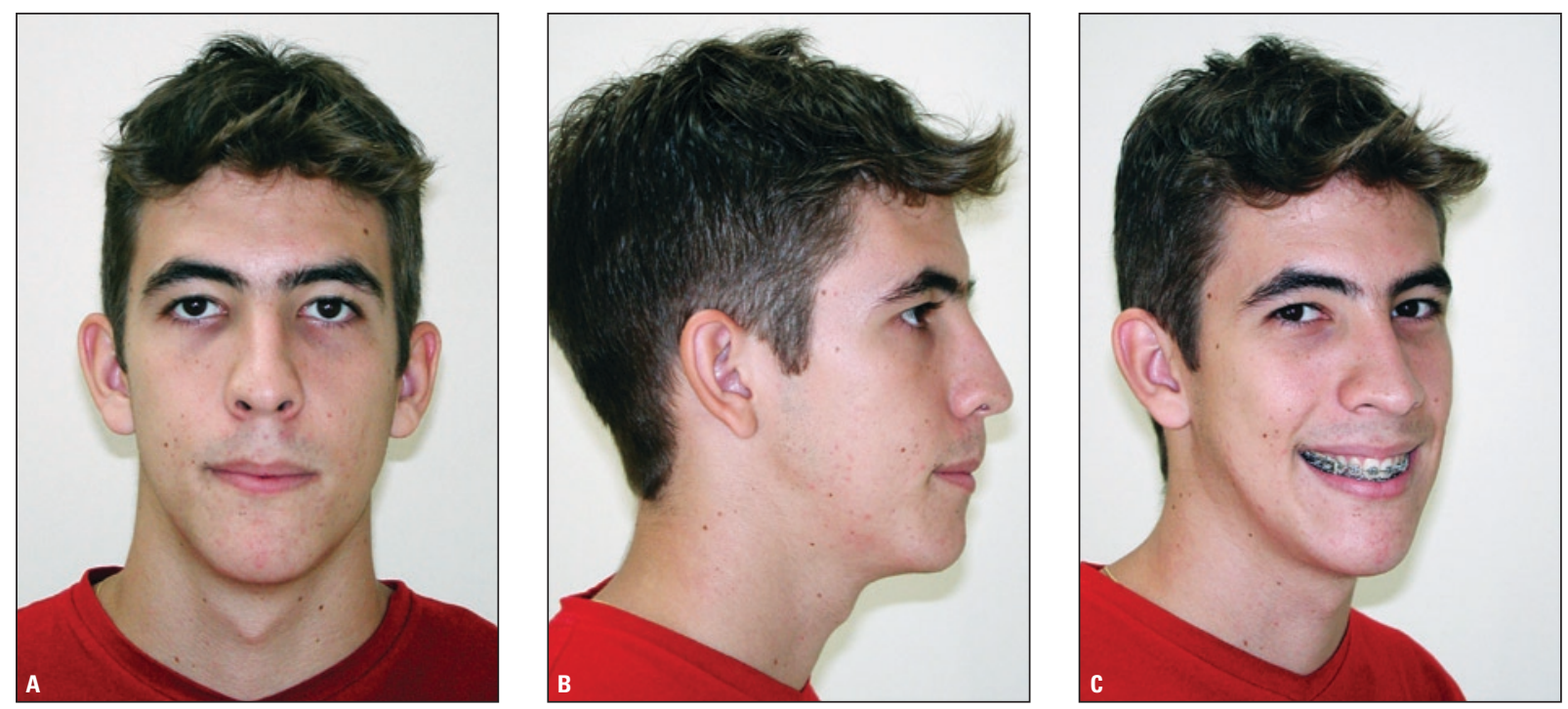

FIGURA 23 - Normalização nas relações faciais pôde ser observada no pós-operatório de um mês, apesar do evidente, porém normal nesta fase, edema pós-operatório. 

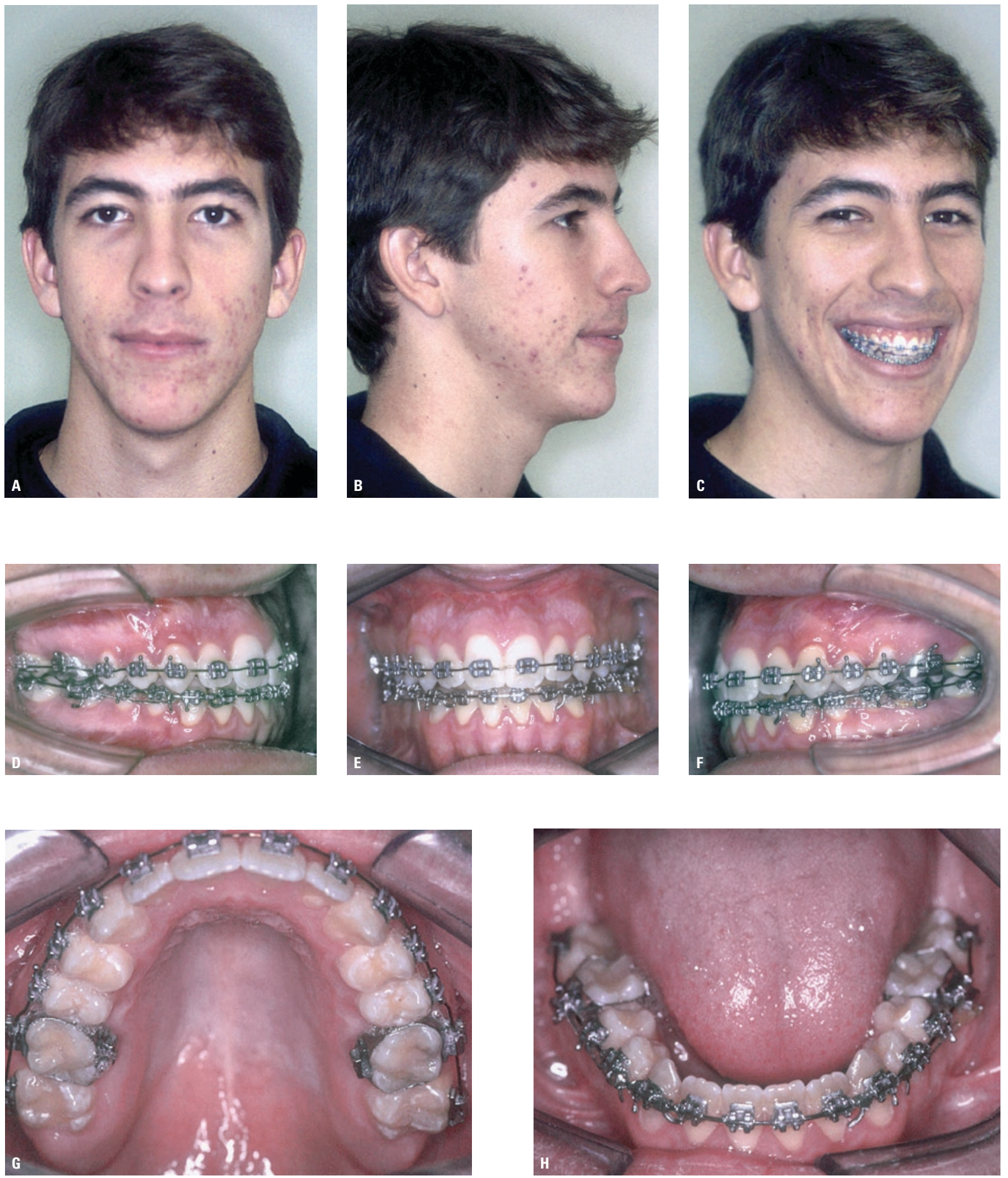

FIGURA 24 - Face (A-C) e oclusão (D-H) ao término da finalização ortodôntica pós-cirúrgica, com duração de 6 meses. Uma evidente melhora das relações faciais e oclusais foi observada, ressaltando a diminuição do edema facial pós-operatório. 

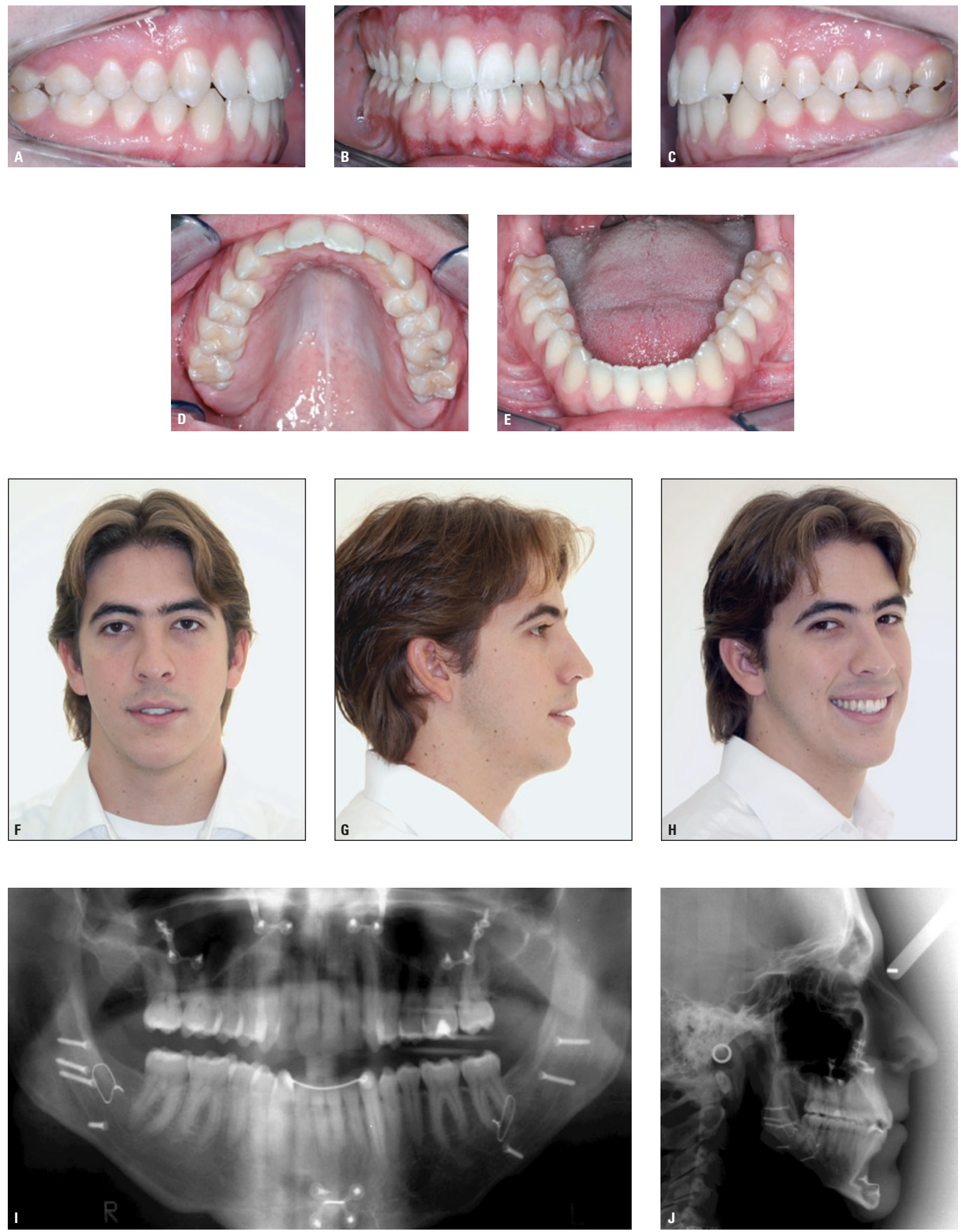

FIGURA 25 - Oclusão (A-E) e face (F-H) aos 22 anos e 6 meses de idade, 2 anos e 3 meses após a remoção dos aparelhos, evidenciavam uma enorme melhora facial e uma boa oclusão, especialmente se for considerado que o paciente não fez uso da contenção superior, a placa de Hawley. 


\section{CONCLUSÕES}

O método proposto por este trabalho, para classificação dos indivíduos portadores das más oclusões do Padrão Face Longa segundo a severidade (moderado, médio e severo), por meio da análise facial e diferentes examinadores, teve sua aplicabilidade testada e permitiu as seguintes conclusões:

- nos resultados obtidos nas avaliações intraexaminadores, todos obtiveram concordâncias substanciais, referenciando confiabilidade diagnóstica;

- as freqüências de concordância diminuíram quando as avaliações interexaminadores foram realizadas. Nesse contexto, a reprodutibilidade do presente método foi considerada moderada;

- esses resultados permitem considerar o método aplicável, com necessidade de complemento de informações provenientes de outros exames rotineiramente aplicados em Ortodontia.
- o uso dessa metodologia pode contribuir para um maior discernimento no diagnóstico, prognóstico e definição de metas terapêuticas para os indivíduos portadores das más oclusões do Padrão Face Longa.

\section{AGRADECIMENTOS}

À empresa Oral B, pelo patrocínio durante a captação dos 125 alunos que compareceram voluntariamente para a realização das fotografias, por meio de kits de escovação.

Ao Centro de Cirurgia e Ortodontia, Unidade de Bauru, Estado de São Paulo, pelo auxílio na captação dos indivíduos da amostra e pela concessão do espaço físico para a realização dos exames.

\title{
Proposal for classification of individuals with long face pattern malocclusions according to severity
}

\begin{abstract}
Aim: The present study aimed to propose a method for classification of long-face patients according to severity, evaluating its reliability and reproducibility. Methods: The study was conducted on facial photographs (frontal, profile and smiling frontal) of 125 long-face children (54 females and 71 males) aged 10 years and 6 months to 15 years and 2 months, selected only on the basis of facial morphology. The photographs were separately evaluated by three examiners and re-evaluated after three weeks in a different random order. The individuals were divided into three subtypes according to severity as mild, moderate and severe. Intra- and inter-examiner agreement was assessed by Kappa (k) statistics. Results: Intra-examiner evaluation revealed substantial agreement, with Kappa values ranging from 0.64 to 0.66 and $80 \%$ or more agreement for all examiners. Evaluation of inter-examiner agreement revealed lower values, ranging from $67.2 \%$ to $70.4 \%$, with Kappa values of 0.41 to 0.46 , thus indicating moderate agreement. Conclusions: Based on these results, the method was regarded as applicable, yet it should be complemented with further information from other examinations routinely applied in Orthodontics. Clinical application will be demonstrated to highlight the different degrees of severity of long face pattern malocclusions and the characteristics of the recommended treatment protocol.
\end{abstract}

Key words: Long face pattern. Deformities. Orthodontic diagnosis. Facial analysis. Severity. 


\section{REFERÊNCIAS}

1. ANGELILLO, J. C.; DOLAN, E. A. The surgical correction of vertical maxillary excess: long face syndrome. Ann. Plast. Surg., Boston, v. 8, p. 64-70, 1982.

2. ARVYSTAS, M. G. Treatment of anterior skeletal open-bite deformity. Am. J. Orthod., St. Louis, v. 72, p. 147-164, 1977

3. BARBRE, R. E.; SINCLAIR, P. M. A cephalometric evaluation of anterior openbite correction with magnetic active vertical corrector. Angle Orthod., Appleton, v. 61, no. 2, p. 93-102, 1991.

4. BELL, W. H. Correction of skeletal type of anterior open bite. J. Oral Surgery, Chicago, v. 29, p. 706-714, 1971

5. BELL, W. H.; CREEKMORE, T. D.; ALEXANDER, R. G. Surgical correction of the long face syndrome. Am. J. Orthod., St. Louis, v. 71, p. 40-67, 1977

6. BISHARA, R. E.; ZIAJA, R. R. Functional appliances: a review. Am. J. Orthod., St. Louis, v. 95, no. 3, p. 250-258, 1989.

7. BJÖRK, A. Prediction of mandibular growth rotation. Am. J. Orthod., St. Louis, v. 55, p. 585-599, 1969.

8. BLANCHETTE, M. E.; NANDA, R. S.; CURRIER, G. F.; GHOSH, J.; NANDA, S. K. A longitudinal cephalometric study of the soft tissue profile of short-and long-face syndromes from 7 to 17 years. Am J. Orthod. Dentofacial Orthop., St. Louis, v.109, p. 116-131, 1996.

9. CANGIALOSI, T. I. Skeletal morphologic features of anterior open bite. Am. J. Orthod. Dentofacial Orthop., St. Louis, v. 85, p. $28-36,1984$.

10. CAPELOZZA FILHO, L. Diagnóstico en Ortodoncia. Maringá: Dental Press, 2004.

11. CAPELOZZA FILHO, L.; CARDOSO, M. A.; REIS, S. A. B.; MAZZOTTINI, R. Surgical-orthodontic correction of long face syndrome. J. Clin. Orthod., Boulder, v. 10, p. 29-42, 2006.

12. CAPELOZZA FILHO, L.; SILVA FILHO, O. G. Reabsorção radicular na clínica ortodôntica: atitudes para uma conduta preventiva. Rev. Dental Press Ortodon. Ortop. Maxilar. Maringá, v. 3, p. 104-126, 1998.

13. CARDOSO, M. A.; BERTOZ, F. A.; REIS, S. A. B.; CAPELOZZA FILHO, L. Estudo das características oclusais em portadores de padrão face longa com indicação de tratamento ortodôntico-cirúrgico. Rev. Dental Press Ortodon. Ortop. Maxilar, Maringá, v. 7, p. 63-70, 2002.

14. CARDOSO, M. A.; BERTOZ, F. A.; CAPELOZZA FILHO, L.; REIS, S. A. B. Características cefalométricas do padrão face longa. Rev. Dental Press Ortodon. Ortop. Maxilar, Maringá, v. 10, p. 29-42, 2005.

15. DUNG, D. J.; SMITH, R. J. Cephalometric and clinical diagnoses of open bite tendency. Am. J. Orthod. Dentofacial Orthop.,St. Louis, v. 94,p. 484-90, 1988.

16. ELMS, T. N.; BUSCHANG, P. H.; ALEXANDER, R. G. Long term stability of Class II, Division 1, nonextraction cervical face-bow therapy: II. Cephalometric analysis. Am. J. Orthod. Dentofacial Orthop., St. Louis, v. 109, no. 4, p. 386-392, 1996

17. EPKER, B. N. Superior surgical repositioning of the maxilla: long term results. J. Maxillofac. Surg., Stuttgart, v. 9, p. 237-246, 1981

18. FIELDS, H. W.; PROFFIT, W. R.; NIXON, W. L.; PHILLIPS, C.; STANEK, E. Facial pattern differences in long-faced children and adults. Am. J. Orthod., St. Louis, v. 85, p. 217-223, 1984.

19. FISH, L. C.; WOLFORD, L. M.; EPKER, B. N. Surgicalorthodontic correction of vertical maxillary excess. Am. J. Orthod., St. Louis, v. 73, p. 241-257, 1978.

20. FITZPATRICK, B. N. The long face and V. M. E. Aust. Orthod. J., Brisbane, v. 8, p. 82-89, 1984.

21. FLEISS, J. L. Statistical methods for rates and proportions. New York: John Wiley \& Sons, 1973.

22. FROST, D. E.; FONSECA, R. J.; TURVEY, T. A.; HALL, D. J. Cephalometric diagnosis and surgical-orthodontic correction of apertognathia. Am. J. Orthod., St. Louis, v. 78, p. 657-669, 1980.
23. GALLANGHER, D. M.; BELL, W .H.; STORUM, K. A. Soft tissue changes associated with advancement genioplasty performed concomitantly with superior repositioning of the maxilla. J. Oral Maxillofac. Surg., Philadelphia, v. 42, p. 238-242, 1984

24. GRABER, T. M.; VANARSDALL JR., R. L. Orthodontics: current principles and techniques. 2 nd ed. St. Louis: C.V. Mosby, 1994.

25. HAGG, U.; TARANGER, J. Maturation indicators and pubertal growth spurt. Am. J. Orthod., St. Louis, v. 82, no. 4, p. 299309, 1982.

26. HANDELMAN, C. S. The anterior alveolus: its importance in limiting orthodontic treatment and its influence on the occurrence of iatrogenic sequelae. Angle Orthod., Appleton, v. 66, no. 2, p. 95-110, 1996.

27. HARALABAKIS, S.; YAGTZIS, S. C.; TOUTOUNTZAKIS, N. M. Cephalometric characteristics of open bite in adults: a three dimensional cephalometric evaluation. Int. J. Adult Orthod. Orthop. Surg., Chicago, v. 9, p. 222-232, 1994.

28. ISAACSON, J. R.; ISAACSON, R. J.; SPEIDEL, T. M.; WORMS, F. W. Extreme variations in vertical facial growth and associated variation in skeletal and dental relations. Angle Orthod., Appleton, v. 41, p. 219-229, 1971

29. LANDIS, J. R.; KOCH, G. G. The measurement of observer agreement for categorical data. Biometrics, Washington, D. C. v. 33, p. 159-174, 1977.

30. LINDER-ARONSON, S.; WOODSIDE, D. G. Excess face height malocclusion: etiology, diagnosis and treatment. [S.I.]: Quintessence, 2000

31. MOLONEY, F.; WEST, R. A.; McNEILL, W. Surgical correction of vertical maxillary excess: a re-evaluation. J. Cranio Max. Fac. Surg., Stuttgart, v. 10, p. 84-91, 1982

32. NAHOUM, H. I. Vertical proportions and the palatal plane in anterior open-bite. Am. J. Orthod., St. Louis, v. 59, p. 273282, 1971.

33. NAHOUM, H. I. Anterior open-bite: a cephalometric analysis and suggested treatment procedures. Am. J. Orthod., St. Louis, v. 67, p. 513-521, 1975

34. NAHOUM, H. I.; HOROWITZ, S. L.; BENEDICTO, E. A. Varieties of anterior open-bite. Am. J. Orthod., St. Louis, v. 61, p. $486-492,1972$

35. NANDA, S. K. Patterns of vertical growth in the face. Am. J. Orthod. Dentofacial Orthop., St. Louis, v. 93, p.103-116, 1988.

36. NANDA, S. K. Growth patterns in subjects with long and short faces. Am. J. Orthod. Dentofacial Orthop., St. Louis, v. 98, p. $247-258,1990$.

37. NGAN, P.; FIELDS, H. W. Open bite: a review of etiology and management. Am. Acad. Pediatr. Dent., Chicago, v. 19, p. 91-98, 1997.

38. NIELSEN, I. L. Vertical malocclusions: etiology, development, diagnosis and some aspects of treatment. Angle Orthod., Appleton, v. 61, no. 4, p. 247-260, 1991.

39. OPDEBEECK, H.; BELL, W. H.; EISENFELD, J.; MISHELEVIC, D. Comparative study between the SFS and LFS rotation as a possible morphogenic mechanism. Am. J. Orthod., St. Louis, v. 74, p. 509-521, 1978.

40. PRITTINEN, J. R. Orthodontic diagnosis of long face syndrome. Gen. Dent., Chicago, v. 44, p. 348-351, 1996.

41. PRITTINEN, J. R. Orthodontic management of long face syndrome. Gen. Dent., Chicago, v. 45, p. 568-572, 1997.

42. SASSOUNI, V.; NANDA, S. Analysis of dentofacial vertical proportions. Am. J. Orthod., St. Louis, v. 50, p. 801-823, 1964.

43. SCHENDEL, S. A.; CARLOTTI JR., A. E. Variations of total vertical maxillary excess. J. Oral Maxillofac. Surg., Philadelphia, v. 43, p. 590-596, 1985.

44. SCHENDEL, S. A.; EISENFELD, J.; BELL, W. H.; EPKER, B. N.; MISHELEVICH, D. J. The long face syndrome: vertical maxillary excess. Am. J. Orthod., St. Louis, v. 70, p. 398$408,1976$. 
45. SOLOW, B.; TALLGREN, A. Natural head position in standing subjects. Acta Odontol. Scand., Stockholm, v. 29, no. 5, p. 591- 607, 1971.

46. SOLOW, B.; TALLGREN, A. Head posture and craniofacial morphology. Am. J. Phys. Anthropol., New York, v. 44, no. 3, p. 417- 436, 1976

47. SUBTELNY, J. D.; SAKUDA, M. Open-bite: diagnosis and treatment. Am. J. Orthod., St. Louis, v. 50, p. 337-358, 1964.

48. TSANG, W. M.; CHEUNG, L. K.; SAMMAN, N. Cephalometric parameters affecting severity of anterior open bite. Int. J. Oral Maxillofac. Surg., Copenhagen, v. 26, no. 5, p. 321-326, 1997

49. VAN DER BEEK, M. C. J.; HOEKSMA, J. B.; ANDERSEN, B. P. Vertical facial growth: a longitudinal study from 7 to 14 year of age. Eur. J. Orthod., Oxford, v. 13, p. 202-208, 1991.

50. LINDEN, P. G. M. van der. The development of long and short faces and their limitations in treatment. Rev. Dental Press Ortodon. Ortop. Facial, Maringá, v. 4, p. 6-11, 1999.
51. VIG, K. W.; TURVEY, T. A. Surgical correction of vertical maxillary excess during adolescence. Int. J. Adult Orthod. Orthognath. Surg., Chicago, v. 4, p. 119-128, 1989.

52. WIESLANDER, L. Long term effect of treatment with headgear: Herbst appliance in the early mixed dentition: stability or relapse? Am. J. Orthod. Dentofacial Orthop., St. Louis, v. 104, no. 4, p. 319-329, 1993.

53. WOLFORD, L. M.; HILLIARD, F. W. The surgical-orthodontic correction of vertical dentofacial deformities. J. Oral Surg. Chicago, v. 39, p. 883-897, 1981

54. WOODS, M. G.; NANDA, R. S. Intrusion of posterior teeth with magnets: an experiment in growing baboons. Angle Orthod., Appleton, v. 58, p. 136-150, 1988.

55. ZAR, J. H. Biostatistical analysis. 3rd ed. Upper Saddle River: Prentice Hall, c1996.
Endereço para correspondência

Leopoldino Capelozza Filho

Rua Padre João N. 14-71

CEP: 17.012-020 - Bauru / SP

E-mail: Icapelozza@yahoo.com.br 